\title{
Does Management Matter in Schools?
}

\section{Citation}

Bloom, Nicholas, Renata Lemos, Raffaella Sadun, and John Van Reenen. "Does Management Matter in Schools?" Economic Journal (Royal Economic Society) 125, no. 584 (May 2015): 647674.

\section{Published Version}

http://onlinelibrary.wiley.com/doi/10.1111/ecoj.12267/abstract

\section{Permanent link}

http://nrs.harvard.edu/urn-3:HUL.InstRepos:17417187

\section{Terms of Use}

This article was downloaded from Harvard University's DASH repository, and is made available under the terms and conditions applicable to Open Access Policy Articles, as set forth at http:// nrs.harvard.edu/urn-3:HUL.InstRepos:dash.current.terms-of-use\#OAP

\section{Share Your Story}

The Harvard community has made this article openly available.

Please share how this access benefits you. Submit a story.

Accessibility 
NBER WORKING PAPER SERIES

DOES MANAGEMENT MATTER IN SCHOOLS

\author{
Nicholas Bloom \\ Renata Lemos \\ Raffaella Sadun \\ John Van Reenen
}

Working Paper 20667

http://www.nber.org/papers/w20667

\author{
NATIONAL BUREAU OF ECONOMIC RESEARCH \\ 1050 Massachusetts Avenue \\ Cambridge, MA 02138 \\ November 2014
}

\begin{abstract}
We would like to thank the ESRC, the IGC, and the Itaú Social Foundation for financial support through the Centre for Economic Performance. Roland Fryer, Gary Chamberlain, Caroline Hoxby, Will Dobbie, Steve Machin, Sandra McNally, Martina Viarengo and participants at seminars in the AEA, Harvard, the Royal Economic Society Conference and Stanford have given helpful comments on earlier drafts. Frederic Vermeulen and two anonymous referees have given excellent advice on the paper. Our partnership with Daniela Scur has been particularly important during this project. Matilde Gawronski and Kalpesh Patil have provided excellent research assistance. The views expressed herein are those of the authors and do not necessarily reflect the views of the National Bureau of Economic Research.
\end{abstract}

At least one co-author has disclosed a financial relationship of potential relevance for this research. Further information is available online at http://www.nber.org/papers/w20667.ack

NBER working papers are circulated for discussion and comment purposes. They have not been peerreviewed or been subject to the review by the NBER Board of Directors that accompanies official NBER publications.

(C) 2014 by Nicholas Bloom, Renata Lemos, Raffaella Sadun, and John Van Reenen. All rights reserved. Short sections of text, not to exceed two paragraphs, may be quoted without explicit permission provided that full credit, including $(\mathcal{C}$ notice, is given to the source. 
Does Management Matter in Schools

Nicholas Bloom, Renata Lemos, Raffaella Sadun, and John Van Reenen

NBER Working Paper No. 20667

November 2014

JEL No. L2

\begin{abstract}
$\underline{\text { ABSTRACT }}$
We collect data on operations, targets and human resources management practices in over 1,800 schools educating 15-year-olds in eight countries. Overall, we show that higher management quality is strongly associated with better educational outcomes. The UK, Sweden, Canada and the US obtain the highest management scores closely followed by Germany, with a gap to Italy, Brazil and then finally India. We also show that autonomous government schools (i.e. government funded but with substantial independence like UK academies and US charters) have significantly higher management scores than regular government schools and private schools. Almost half of the difference between the management scores of autonomous government schools and regular government schools is accounted for by differences in leadership of the principal and better governance.

Nicholas Bloom

Stanford University

Department of Economics

579 Serra Mall

Stanford, CA 94305-6072

and NBER

nbloom@stanford.edu

Renata Lemos

Center for Economic Performance

London School of Economics

Houghton Street

London WC2A 2AE

UK

and University of Cambridge

r.lemos@1se.ac.uk

Raffaella Sadun

Harvard Business School

Morgan Hall 233

Soldiers Field

Boston, MA 02163

and NBER

rsadun@hbs.edu

John Van Reenen

Department of Economics

London School of Economics

Centre for Economic Performance

Houghton Street

London WC2A 2AE

UNITED KINGDOM

and NBER

j.vanreenen@1se.ac.uk
\end{abstract}




\section{INTRODUCTION}

There are major disparities in the quality of education within and between countries (e.g. OECD 2012). School managerial practices may be an important reason for such differences. Unfortunately, understanding the role of management in schools within and across countries has been held back by a lack of robust and comparable instruments to systematically measure management practices and, thus, a lack of good data.

The key purpose of this paper is to develop an international management index for schools and present descriptive evidence on management quality and education outcomes across schools of different types within and across countries. We used double-blind telephone interviews with school principals to collect information on management practices for over 1,800 schools across eight countries. To construct our management index, we average across 20 basic management practice measures in four areas of management: operations, monitoring, target setting and people. Each question is evaluated against a scoring grid that ranges from one ("worst practice") to five ("best practice"). Our management index for each school represents the average of these scores.

We also constructed measures of school-level pupil outcomes for these schools (when data was available) from examination results across regions and countries, creating a matched management-pupil outcome international dataset at the school level.

This data allows us to document some stylized facts. First, we show that the adoption of basic managerial practices varies significantly across and within countries. The UK, Sweden, Canada and the US obtain the highest average scores, followed by Germany, Italy and Brazil, while India has the lowest scores. About half of the variance in school management is at the country-level. This share is larger in education than we have found from our similar surveys in other sectors such as manufacturing, where most of the variation is within countries. This finding suggests that differences in the institutional environment have particularly important effects on the way schools are managed.

Second, higher management scores are positively correlated with better pupil outcomes. More specifically, we find that one standard deviation increase in our managerial index is associated with a 0.232 to 0.425 standard deviation increase in pupil outcomes. Although the 
cross-sectional nature of the data does not allow us to determine whether this correlation is causal (e.g. unobservable differences across schools might drive both pupil outcomes and management quality), the result does suggest that our management data has some useful informational content.

Third, large disparities in management also exist within countries and regions, especially across types of schools. In particular, autonomous government schools - organisations that are publicly funded but are more decentralised from government control, like charter schools in the US and academies in the $\mathrm{UK}^{1}$ - have significantly higher management scores than regular government schools and private schools. The difference in management of autonomous government schools does not reflect observable differences in pupil composition, school and regional characteristics, nor basic demographics or principal characteristics such as tenure and gender. It does, however, seem more closely linked to two features: (i) the strength of governance, i.e. having strong accountability for pupil performance to an outside body and (ii) the degree of school leadership, i.e. developing a long-term strategy for the school. Including these governance and leadership variables more than halves the managerial gap between autonomous government schools and other schools (although the gap remains significant).

Previous efforts to survey school practices support our main findings. For example, Dobbie and Fryer (2013) and Angrist, Pathak, and Walters (2013) have collected extensive measures of school practices, focusing on a smaller sample of US schools. Dobbie and Fryer (2013) report in a sample of 39 New York charter schools that management practices similar to those we measure - in particular teacher feedback, data guided instruction and high expectations are associated with substantially higher grades. Angrist, Pathak, and Walters (2013) survey a sample of 36 Massachusetts charter schools and link the impact of urban charter schools ${ }^{2}$ to practices such as instructional time, classroom technique and school philosophy - labelled the "No Excuses" approach. Intriguingly both papers also find little or no impact of schools

\footnotetext{
${ }^{1}$ We define autonomous government schools as schools receiving at least partial funding from the government and with at least limited autonomy to follow school-specific charters in one of three areas: establishing the curriculum content, selecting teachers, and admitting pupils. In our data, these are escolas de referência in Brazil, separate schools in Canada, private ersatzschulen in Germany, private-aided schools in India, friskolor in Sweden, academies, foundation, and voluntary-aided schools in the UK (equivalent to autonomous state schools), and charter and magnet schools in the US. See Table 1 for more details.

${ }^{2}$ The authors find more mixed results for the non-urban charter schools.
} 
inputs - class size, per-pupil expenditure or teacher training - on pupil performance, a result shared with Hannushek and Woessmann (2010) on a cross country basis.

In our data collection efforts, we focus on a set of basic management practices, which we have shown to matter across other sectors (see the survey of this work in Bloom, Lemos, Sadun, Scur, Van Reenen 2014). The school data is less rich and does not have the compelling experimental design of the New York and Massachusetts data, however we have a much larger sample of schools and an international dimension. Our results extend the current literature by highlighting the variance of management quality in schools within and across countries, the relatively low management quality on an absolute level compared to other sectors, and its widespread link to pupil outcomes and autonomy levels across countries,

This paper also contributes to several literatures. Firstly, we link to work on the role of institutions for school performance, focusing in particular on their implications for management practices. Many recent contributions (e.g. from the OECD's PISA studies) have also looked at this through the lens of autonomy, centralized monitoring, school choice, teacher incentives and instructional time. ${ }^{3}$ Secondly, there is a burgeoning number of studies on alternative types of school governance and management on pupil outcomes. These studies have focused on autonomous government schools, such as US urban charter schools. ${ }^{4}$ Thirdly, through the analysis of principal-specific characteristics we relate to the agenda investigating the effect of school leadership. ${ }^{5}$ Finally and more generally, we contribute to the emerging literature investigating management practices in public sector institutions. ${ }^{6}$

The remainder of this paper is organized as follows: Section II describes the data and methodology we used to measure management practices across schools. Section III provides

\footnotetext{
${ }^{3}$ For examples see Hanushek and Woessmann (2010), Fuchs and Woessmann (2007), Woessmann et al. (2007), Woessmann (2005), Woessmann (2010), Hanushek, Link, and Woessmann (2013), and Lavy (2010).

${ }^{4}$ For examples of studies looking at US urban charter schools see Abdulkadiroglu et al. (2011), Angrist, Pathak, and Walters (2013), Angrist et al. (2011), Fryer (2014), Dobbie and Fryer (2011, 2013), Curto and Fryer (2014), and Hoxby and Murarka (2009). Other studies looking at US rural charter schools include Angrist et al. (2011), UK academies include Eyles and Machin (2014), Machin and Vernoit (2011), and Clark, Martorell, and Rockoff (2009), Swedish friskolor include Sahlgren (2011) and Böhlmark and Lindahl (2012) and Canadian separate schools include Card, Dooley, Payne (2010).

${ }^{5}$ For examples see Branch, Hanushek, and Rivkin (2012), Dhuey and Smith (2011), Coelli and Green (2012), Clark, Martorell, and Rockoff (2009), Béteille, Kalogrides, and Loeb (2012), Grissom and Loeb (2011), and Horng, Klasik, and Loeb (2010).

${ }^{6}$ For examples see Bloom, Propper, Seiler and Van Reenen (2015), McCormack, Propper, and Smith (2013), Rasul and Rogger (2013).
} 
a basic description of the differences in school management across and within countries. Section IV investigates the relationship between school management practices and pupil outcomes. Section V explores the factors linked to the variation of management practices across countries, examining the role of school ownership and governance within countries. Section VI concludes.

\section{DATA}

\section{Measuring management practices in education}

To measure management practices in schools, we adapted a survey methodology described in Bloom and Van Reenen (2007), previously employed in the manufacturing, retail and healthcare sectors. The survey investigates the adoption of 20 basic management practices, where the level of adoption is evaluated against a grid from one to five. ${ }^{7}$ A high score indicates that a school adopts structured practices. Our main measure of management practices represents the average of the scores across all 20 questions. To ensure comparability across sectors, we retained most of the questions included in our previous studies of organizations in other sectors, with modifications to reflect the school context (the full list of questions can be found in Table A1). ${ }^{8}$ We interviewed the principal/head teacher in each school.

We measure four broad areas of management:

\section{Operations}

Standardization of Instructional Planning Processes: school uses meaningful processes that allow pupils to learn over time

Personalization of Instruction and Learning: school incorporates teaching methods that ensure all pupils can master the learning objectives

Data-Driven Planning and Pupil Transitions: school uses assessment and easily available data to verify learning outcomes at critical stages

\footnotetext{
${ }^{7}$ In the earlier manufacturing-focused survey wave we carried out an extensive evaluation of this approach, including comparing telephone interviews with face-to-face visits, running management experiments on firms, and resurveying $5 \%$ of the sample with different interviewers and managers at the same firm. In all cases we found strong evidence that our telephone surveys were providing a good proxy of firm management practices see Bloom, Genakos, Sadun and Van Reenen (2012) for details.

${ }^{8}$ Sixteen of these twenty basic practices are considered to be relevant and applicable across all industries previously surveyed (for example, performance based promotion) while the remaining four are specific to the management of schools (for example, lesson planning).
} 
Adopting Educational Best Practices: school incorporates and shares teaching best practices and pupil strategies across classrooms accordingly.

\section{Monitoring}

Continuous Improvement: school implements processes towards continuous improvement and encourages lessons to be captured and documented

Performance Tracking: school performance is regularly tracked with useful metrics

Performance Review: school performance is reviewed with appropriate metrics

Performance Dialogue: school performance is discussed with appropriate content, depth and communicated to teachers.

Consequence Management: mechanisms exit to follow-up on performance issues

\section{Target Setting}

Target Balance: school covers a sufficiently broad set of targets at the school, department, and individual levels

Target Interconnection: school establishes well-aligned targets across all levels

Time Horizon of Targets: there is a rational approach to planning and setting targets

Target Stretch: school sets targets with the appropriate level of difficulty

Clarity and Comparability of Targets: school sets understandable targets and openly communicates and compares school, department and individual performance

\section{People Management ${ }^{9}$}

Rewarding High Performers: school implements a systematic approach to identifying good and bad performance, rewarding teachers proportionately.

Fixing Poor Performers: school deals with underperformers promptly

Promoting High Performers: school promotes employees based on job performance

Managing Talent: school nurtures and develops teaching and leadership talent

Retaining Talent: school attempts to retain employees with high performance

Creating a Distinctive Employee Value Proposition: school has a thought-through approach to attract employees

\footnotetext{
${ }^{9}$ These practices are similar to those emphasized in earlier work on management practices, by for example Black and Lynch (2001), and Ichniowski, Shaw, and Prennushi (1997).
} 


\section{Obtaining school surveys across countries}

We randomly sampled schools that offered education to 15-year-olds and had at least 50 pupils. These schools are large enough that the type of systematic management practices we study here are likely to matter. ${ }^{10}$ We used a variety of procedures to remove potential sources of bias from our estimates. First, we monitored interviewers' performance in contacting schools and scheduling interviews. The interviewers ran on average two interviews a day lasting approximately an hour each and spent the remainder of their time repeatedly contacting principals to schedule interviews. Second, we presented the study as a confidential conversation about management experiences, starting with non-controversial questions such as "What is your school's plan for the next five years?" and "What tools and resources are provided to teachers?" Third, we never asked principals about the school's overall pupil performance during the interview. Instead, we obtained such data from other sources, which were usually from administrative information (described in Appendix A). Fourth, we sent informational letters and copies of endorsements letters from respected institutions, such as the UK Department for Education, Harvard University's Program on Education Policy and Governance, and Brazil's Itaú Social Foundation. ${ }^{11}$

In terms of interviews completed, we obtained an overall high response rate $(41 \%$ on average $^{12}$ ), ranging from $58 \%, 57 \%$ and $42 \%$ of eligible schools in Brazil, Italy and India, respectively, to $36 \%, 26 \%, 20 \%$ and $19 \%$ of eligible school in Sweden, Germany, the US and Canada. We obtained a substantially lower response rate in the UK $-8 \%$ of eligible schools most likely due to the proliferation of cold-calling and the increasing number of telephone surveys in schools in the UK, and principals' slow turnaround time for a response after the initial contact by interviewers (which was common throughout the North American and European countries surveyed).

The response rate of $41 \%$ is similar to our previous manufacturing and healthcare surveys. It is also roughly comparable to other management surveys in education such as $64 \%$ response rate of middle and high schools in Massachusetts, US (Angrist, Pathak, and Walters, 2013),

\footnotetext{
${ }^{10}$ In Brazil, Canada, Italy, Germany, US, and UK, these schools are part of the upper secondary or high school education system. In India these schools are part of the lower secondary education system while in Sweden they are still considered primary schools.

${ }^{11}$ Despite the common practice of paying organizations to participate in research, we did not provide managers with financial incentives to participate.

${ }^{12}$ Average weighted by the number of interviews in each country.
} 
57\% response rate of UK University departments (McCormack, Propper and Smith, 2014), and $39 \%$ response rate of New York Charter schools (Dobbie and Fryer, 2013). ${ }^{13}$

However, when interviewers were able to connect with school principals, they typically agreed to the survey proposition when interviewers were able to connect with them. As such, the explicit refusal rate among eligible schools was generally low across all countries surveyed, ranging from 2\% in Sweden, $6 \%$ in both the US and Canada, 9\% in India, 13\% in both Brazil and the UK, $15 \%$ in Italy and to $16 \%$ of all eligible schools in Germany. In terms of selection bias, we compare our sample of schools for which we secured an interview with the sample of eligible schools in each country against size, ownership, and location. We obtain few significant coefficients with marginal effects small in magnitude. We further construct sampling weights and observe that our main unweighted results stand even when using alternative sample weighting schemes. We describe our selection analysis as well as the sampling frame sources and response rates in more detail in Appendix C.

\section{Maximizing response rates and interview quality}

We also followed several steps to obtain a high quality response. First, we use a "doubleblind" interview technique. That is, at one end, we conducted the telephone survey without informing the principals that their answers would be evaluated against a scoring grid. Thus, we gathered information about actual management practices as opposed to the principal's aspirations of what should (rather than does) happen. At the other end, our interviewers did not know in advance anything about the school's performance. Interviewers were only provided with the school's name and telephone number and had generally not heard of the schools on their lists before, thus, having no preconceptions about them.

Second, we used open-ended questions - that is, questions which avoid leading responders towards a particular answer. For example, on the first performance monitoring dimension we start by asking the open question "What kind of main indicators do you use to track school performance?", rather than a closed-ended question like "Do you use class-room level test scores indicators [yes/no]?". The first open-ended question is followed by further questions

\footnotetext{
${ }^{13}$ Other establishment survey response rate benchmarks include at the high-end the US Census response rates to the mandatory Management and Organizational Practices Survey at 80\% (Bloom, Brynjolfsson, Foster, Jarmin, Saporta and Van Reenen, 2013), in the mid-range the 30\% response rate of small firms by Aurora, Cohen and Walsh (2014), down to the 7\% response rate for Chief Financial Officers at medium and large firms (BenDavid, Graham and Harvey, 2013).
} 
like "How frequently are these indicators measured?", "Who gets to see this data?" and then "If I were to walk through your school what could I tell about how you are doing against your indicators?" The combined responses to this dimension are scored against a grid which goes from 1 - defined as "Measures tracked do not indicate directly if overall objectives are being met. Tracking is an ad-hoc process (certain processes aren't tracked at all)." up to 5 defined as "Performance is continuously tracked and communicated, both formally and informally, to all staff using a range of visual management tools." During their training session, the interviewers are also encouraged to ask follow-up questions whenever necessary.

Third, we had rigorous interviewer training. We required all interviewers to undergo one week of initial training, including multiple group scoring sessions to ensure consistency across countries. ${ }^{14}$ We also required them to conduct and listen to at least 25 interviews to correct any inconsistent interpretation of responses. Fourth, we "double-scored" the majority of interviews (69\%). That is, we asked the team managers, whose main role was monitoring, to silently listen and score the responses provided during each interview. After the end of the interview, the team manager discussed these scores with the primary interviewer, providing on-going training and calibration.

Finally, we also collected "noise-controls", that is, data on the interview process itself (such as the time of day and the day of the week), characteristics of the interviewee and the identity of the interviewer. We include these noise controls in the regression analysis to improve the precision of our estimates by reducing some of the measurement error.

\section{Choosing countries to survey}

The choice of countries was driven by funding availability, the availability of school sampling frames, and research and policy interest. We are continuing to roll these school management surveys out across countries, for example hoping to extend this shortly to China, Denmark and Mexico through collaborations with other research institutions.

\footnotetext{
${ }^{14}$ During these calibration exercises, the whole team listened to both created role-play interviews and actual live interviews (in English) then subsequently compared scores. Any differences in scoring were discussed to ensure a common interpretation of the scoring grid. These calibration sessions were run intensively at the beginning and then periodically through-out the project (to avoid any interviewers scoring drifting over time).
} 


\section{Classifying differences across school types}

In order to look at management practices across different types of schools, we classify regular government schools, autonomous government schools and private schools based on two main characteristics: their source of funding and their degree of autonomy in establishing the curriculum content, selecting teachers, and admitting pupils. Regular government schools receive full funding from the government (national or local level) and follow governmentwide rules and regulations with little or no autonomy in these three areas. Private schools receive solely private funding (they may be for-profit or not-for-profit) and follow schoolspecific charters, having full autonomy over all three areas mentioned above. Autonomous government schools receive most of their funding from the government but have more autonomy to follow school-specific charters on curriculum, teacher selection and (sometimes) limited pupil selection. ${ }^{15}$

Table 1 classifies school types across these areas. By this criteria we defined the following types of schools as autonomous government schools: Escolas de Referência (Brazil); Separate Schools (Canada); Private Ersatzschulen (Germany), Private-Aided Schools (India); Friskolor (Sweden); Academy, Foundation and Voluntary-Aided Schools (UK); and Charter and Magnet Schools (US). There are no autonomous government schools in Italy.

Appendix Table B1 presents means and standard deviations of our variables for the overall sample and Table B2 breaks them down by country and shows differences across private, autonomous government and regular government schools in deviations from country means. In the OECD countries and Brazil autonomous government schools have higher management scores than both regular government schools and private schools. India looks different with private schools scoring most highly. However, Table B2 also shows that autonomous government schools are systematically different on many dimensions. For example, they are smaller than regular government schools and more likely to be in urban areas. Our analysis will consider whether the apparently higher management scores (and pupil performance) of such schools is due to such confounding influences.

\footnotetext{
${ }^{15}$ Pupil selection in autonomous government schools is usually not based on academic ability (although we will analyse this) but rather on other dimensions. For example, UK academies can select up to $10 \%$ of pupils on "aptitude" (such as sporting or musical ability).
} 
Collecting measures of pupil performance

Given the absence of publicly comparable metrics of school-level performance across countries, ${ }^{16}$ we collected several country-specific measures of educational achievement ranging from standardized (and sometimes compulsory) examination results to nonstandardized examination results.

We use the following main measures in each country: (1) In the US we construct measures of school performance using the math, science and reading exam pass rate from High School Exit Exams (HSEEs) and End-of-Course (EOCs) exams in states where performance measures were available. (2) In the UK we employ the average uncapped GCSE score, the contextual value added measure, and the proportion of pupils achieving five GCSEs (level 2) including English and Maths. (3) In Canada we employ the school-level rating produced by the Fraser Institute, which is based on several measures of pupil achievement, including average province exam mark, percentage of exams failed, courses taken per pupil, diploma completion rate, and delayed advancement rate. (4) In Sweden we use the GPA in the $9^{\text {th }}$ grade and the percentage of pupils qualifying for upper secondary school. (5) In Brazil we use the average scores for math, natural sciences, and language and codes of the nonmandatory High School National Exam (Exame Nacional do Ensino Medio, ENEM). We also use 9th grade average score of Prova Brasil for government schools. (6) In India we use the average scores for math, science and first language in the X Standards examinations. The details of these measures and their sources for each country and are provided in Appendix A.

\section{SCHOOL MANAGEMENT ACROSS AND WITHIN COUNTRIES}

Figure 1 shows the average management scores across countries. The adoption of modern managerial processes in schools is fairly limited: on an index of 1 to 5 , the average management score across all countries is 2.27 , which corresponds to a low level of adoption of many of the managerial practices included in the questionnaire. There are, however, significant differences across countries. The UK has the highest management score (2.9), closely followed by Sweden, Canada and the US (all on 2.8). Germany is slightly lower (2.5) and Italy is substantially lower (2.1). The emerging economies of Brazil (2.0) and India (1.7) have the lowest scores. The rankings do not change substantially when we include school and

\footnotetext{
${ }^{16}$ The main exception to this, which is relevant to our study of schools offering education to 15 -year olds, is the pupil level data on achievement collected in the framework of the PISA project. Unfortunately due to confidentiality constraints the PISA data cannot be released with school identifiers. We were therefore unable to match the two datasets.
} 
principal controls suggesting that these differences in management are not driven by school, principal or interviewee characteristics. ${ }^{17}$

Differences in management across countries are larger in education than in other sectors. Country fixed effects account for $46 \%$ of the variance in the school management scores compared to $13 \%$ in manufacturing and $40 \%$ in hospitals across the same subset of countries and questions. This finding suggests that institutions play an important role in management practices in the education sector (Fuchs and Woessmann 2007).

Figure 2 shows the differences across countries, splitting the management index into people management practices (hiring, firing, pay and promotions) and other non-people management practices (operations, monitoring and target setting). Interestingly, there are some clear variations in relative strengths and weaknesses. Across all countries, schools are notably weaker in people management practices.

Figure 3 shows the distribution of the management scores within each country with the smoothed (kernel) fit of the US for comparison. Across OECD countries, lower average country-level management scores are associated with an increasing dispersion towards the left tail of the distribution: every country except the UK has some schools scoring below two. A score of below two indicates very poor management practices - almost no monitoring, very weak targets (e.g. only an annual school-level target) and extremely weak incentives (e.g. tenure based promotion, no financial or non-financial incentives and no action taken about underperforming teachers). However, while the fraction of schools scoring between one and two is minimal in countries such as Sweden and Canada (2.2\% and $2.7 \%$, respectively), it rises to $82 \%$ in India.

At the other end of the distribution, we also observe that all OECD countries have some schools scoring on average above three, which in contrast would correspond to medium to widespread adoption of the management practices (some reasonable performance monitoring, a mix of targets and performance based promotion, rewards and steps taken to address persistent underperformance). The fraction of schools scoring above three ranges from $46 \%$ in the UK to $5 \%$ in Italy. While the distribution of management scores for Brazil is very

${ }^{17}$ We look in more detail at sample selection in Appendix C, Table C4. 
similar to the Italian distribution (a wide dispersion of scores and a "fat" left tail of weakly managed schools), India is clearly different from the OECD countries. In India the distribution of the management scores shifts completely to the left: the vast majority of schools scores below two, and no school scores above three, indicating that Indian schools seem to have very weak management practices, with very little monitoring, target setting and use of monetary and non-monetary incentives. Looking at a comparable set of practices across other sectors, we find that the fraction of Indian firms scoring above three is $22 \%$ for manufacturing and $10 \%$ for hospitals, compared to only $1.6 \%$ for schools. This finding matches up to the long literature on poor management practices in Indian schools. ${ }^{18}$

Figure 4 plots the distribution of management scores for three sectors for the US and the UK. It is striking that for the US the mean of the distribution is lowest for schools, in the middle for hospitals and highest for manufacturing firms in the US. ${ }^{19}$ For the UK schools are in the middle of the three industries - above hospitals and below manufacturing. We can also compare our scores to those for University departments collected by McCormack, Propper and Smith (2014) in the UK. This reports a similarly wide dispersion of management practices in UK universities, with a moderately higher mean. There is also a significant positive relationship between university management practices on the one hand and academics' performance in research and teaching on the other. In the next sub-section we will show that the positive association between management and student performance also exists for our sample of schools.

\section{MANAGEMENT QUALITY AND EDUCATIONAL OUTCOMES}

Are our management scores related to meaningful educational outcomes? While we are by no means able to establish whether management is causally related to improvements in educational achievements, we see this analysis as a useful external validation exercise of our management data. ${ }^{20}$ If the management data were just noise, there should be no systematic relationship between management and objective information on pupil performance.

\footnotetext{
${ }^{18}$ See, for example, Duflo, Hanna and Ryan (2012) and the literature discussion therein.

${ }^{19}$ In contrast to the average school score of 2.27 across all eight countries, the average manufacturing firm scores 3.01 for the same eight countries (firms employing 50 to 5000 workers). The average school also scores lower but more similarly to the average hospital (general hospitals offering acute care plus cardiology or orthopedics procedures), where the average score is 2.43 across these eight countries.

${ }^{20}$ The association between management and firm performance has already been empirically tested in other sectors outside education, including manufacturing, hospitals and retail (e.g. Bloom et al., 2012). Better management practices have also been associated with better outcomes for workers, with for example, Bloom et
} 


\section{Empirical model of pupil performance}

We consider a base simple "educational production function", ${ }^{21}$ where school-level average pupil exam outcomes $\left(Y_{i c}\right)$ are related to pupil composition, management and other schoollevel characteristics, where $i$ denotes individual schools and $c$ denotes country. We are particularly interested in the coefficient on the management index ( $M$ is the average of the $\mathrm{z}$ scores of each of the 20 individual z-scores of the management questions).

$$
Y_{i c}=\beta^{M} M_{i c}+\beta^{A U T G O V} A U T G O V_{i c}+\beta^{P R I} P R I V A T E_{i c}+\gamma^{X} X_{i c}+u_{i c}
$$

We focus on the three types of school discussed above: autonomous government schools (AUTGOV), private schools (PRIVATE), and regular government schools as the omitted base. $X$ are the other controls detailed below and $u_{i c}$ is an error term. To control for some of the other dimensions that may differ across type of school we include the type of curriculum (the regular academic school programs vs. vocational/technical education) and whether the school can select pupils based on academic merit.

Our empirical proxies for educational outcomes are school-level measures of pupil achievement as described the subsection II above and Appendix A. In summary, we use country-specific measures of educational achievement as follows: the percentage of pupils who passed their secondary school core subject exit exams (US), the percentage of pupils who qualified for upper secondary school (Sweden), the average overall score and subjectspecific scores for secondary school exit examinations (India, Sweden, and UK), rankings and contextual value added based on several indicators including pupil grades and characteristics (Canada and UK), and mandatory and non-mandatory university entrance qualification national exams (Brazil). Given the differences in school-level indicators of pupils' achievement across countries, we standardize outcome measures within each country and include country dummies in all specifications when we pool across countries.

We control for school resources and inputs by including measures of the number of pupils in the school, the pupil/teacher ratio, and a dummy to capture schools that select pupils partially

al. (2011) reporting well-managed firms have better facilities for workers such as child-care facilities, job flexibility and self-assessed employee satisfaction.

${ }^{21}$ See Hanushek (1979) for a conceptual and empirical discussion of education production functions. 
based on academic merits. More detailed controls for pupil characteristics depend on the data available for each country. These include the proportion of pupils who are female, non-white, who do not speak the national language as their primary language, and who are eligible for free school meals (a standard poverty measure). We consider specifications that estimate equation (1) by pooling across all countries and using only basic controls for pupil composition, but we also show specifications where we estimate the equation separately for each country where we can control for pupil composition in finer detail (at the cost of smaller sample sizes). Finally, some specifications control for survey measurement error by including interviewer dummies, a subjective interview reliability indicator coded by the interviewer, the day of the week, time in which the interview took place and interview duration.

We have a sample of just over 1,000 schools when we estimate equation (1). This smaller sample size is mainly because we do not have access to school level performance data in Italy and Germany. ${ }^{22}$ However, we do find a positive relationship between the average PISA pupil performance score and the average management score in German regions (correlation of 0.65, significant at the $10 \%$ level) and Italian regions (correlation of 0.63 , significant at the $5 \%$ level). ${ }^{23}$

\section{Main results on pupil performance}

Table 2 presents the results of regressing school-level measures of pupil achievement on the management score. Looking at the table as a whole, management quality is positively correlated with pupil achievement across all countries. Column (1) reports the cross-country pooled regression with controls only for country dummies. The coefficient implies that a one standard deviation increase in the management score index (0.65 points in the raw management score) is associated with an increase of 0.425 of a standard deviation in pupil achievement. Column (2) includes the dummy variables for school type. Private schools and

\footnotetext{
${ }^{22}$ There are also a portion of schools in the other six countries where we could not obtain performance data. For example, in the US we did not find public information on pupil performance in private schools, we did not collect performance data in states where we interviewed only one school or states which do not have a High School Exit Exam or End-of-Course Assessments. In India we collected performance measures over the telephone by calling back the school and speaking to the exams coordinators (response of 50\%) and were also not able to collect information with a number of private schools no longer requiring their students to take the $\mathrm{X}$ Standard Examinations. In Canada, the Fraser Institute 2009 school ratings were only collected in Alberta, British Columbia, and Ontario. Thus, in the US, India and Canada, we were not able to collect performance data for approximately $47-53 \%$ of the sample. In Brazil, Sweden and the UK, we did not find public information for a very small portion of the schools surveyed (approximately $7-8 \%$ in each).

${ }^{23}$ We use 2006 PISA regional average scores for 8 German regions and 2009 PISA regional average scores for 14 Italian regions, restricting to regions with 5 or more observations.
} 
autonomous government schools obtain significantly higher pupil outcomes than regular government schools. If we drop the management variable, the coefficient on these school types rises substantially. ${ }^{24}$ We will return to the difference between school types in the next table.

Column (3) includes the set of more general controls which slightly decreases the coefficient on management to 0.232 , and it remains significant at the $1 \%$ level. ${ }^{25}$ The magnitude remains sizeable. For example, a one standard deviation improvement in management is equivalent to $49 \%$ of the improvement associated with the selection of pupils based on academic merit. In terms of the other characteristics larger schools have higher performance as do those with a higher teacher-pupil ratio (although not significantly so).

In columns (4) to (9) we disaggregate by country and add a richer set of country-specific controls. Across all countries, management quality continues to be positively associated with better pupil outcomes and in most countries this relationship is significant at the $10 \%$ level or greater. ${ }^{26}$ The correlation is largest in Canada (0.609) and smallest in Brazil (0.104). ${ }^{27}$ It is difficult to interpret the reasons for the cross-country differences given the different measures of test scores. Some of the differences in significance are related to sample size: the only two countries with a statistically insignificant coefficient on management are the two with the smallest number of schools (Canada has a sample size of 77 and Sweden has 82). We do not find a systematically larger coefficient in the "Anglo-Saxon" countries (e.g. the US coefficient on management is smaller than the one in India), which is consistent with the view that the management measure are not inherently culturally biased.

\footnotetext{
${ }^{24}$ For example the coefficient on autonomous government schools rises from 0.23 to 0.30 .

${ }^{25}$ To put this result into perspective in view of the larger literature using educational production functions, Rivkin, Hanushek, and Kain (2001) find that a one standard deviation reduction in class size (roughly 3 pupils per class) is associated with a 0.02 of a standard deviation increase in achievement. Hanushek and Rivkin (2003) find that a one standard deviation increase in the degree of competition ( 0.02 point decline in the Herfindahl Index) is associated with a reduction of 0.09 standard-deviations in the within school variance of teacher quality. In other words, performance associations for management quality are between 2 to 3 times as large as for competition and teacher quality and over ten times as large as for a measured input such as class size.

26 In a companion paper, Di Liberto, Schivardi and Sulis (2013) find a positive and weakly significant association between nationally-tested student level math exams outcomes in Italy and our management measures.

${ }^{27}$ In Table B3 we report the results of the association between pupil outcomes and management using alternative measures of pupil outcomes. The majority of the results are consistent with Table 2, i.e. management is positively and significantly associated with most available school-level measures of pupil outcomes.
} 
A criticism of the results in Table 2 is that we are not fully controlling for the fact that pupil intake is very different across schools, so it may be that the better managed schools are simply lucky enough to have better quality students sorting into these schools. For one country (the UK) there are published school-level measures of value added, which tracks the average improvement in pupils' grades between entering and exiting the school. Such value added measures are superior to just using test score measures as their control for initial intake quality. Column (10) uses value added as an outcome and shows that our management score actually displays a statistically and economically stronger correlation with this value added measure than the raw test score measure in the previous column (0.881 vs. 0.512). Hence, although we do not have value added measures for all countries, it seems unlikely that differential student intake is driving the results in Table 2.

\section{Robustness of pupil performance results}

Appendix Table B4 presents some robustness tests of the results of regressing school-level measures of pupil achievement on the management using column (3) of Table 2 as a baseline. The management survey includes several questions related to people management (e.g. use of incentives, practices related to promotion and dismissals of teachers) that are heavily regulated across most of the countries in our sample. One possible concern is that regulatory constraints might reduce the observed variation along these areas of management, thus inhibiting our ability to estimate their association with school-level pupil outcomes. We look at this issue in two ways. First, the distribution of people management by country shows substantial within country variation (Appendix Figure B1). This finding suggests that national regulations are not homogenous or completely binding on schools. Second, people management alone is positively and significantly correlated with school-level outcomes, with a coefficient (standard error) of $0.257(0.046)$ in an equivalent specification to column (5) of Table B4. The other non-people related areas of management are also significantly correlated with outcomes - coefficients (standard error) of 0.093(0.036) for operations, $0.133(0.036)$ for performance monitoring, and $0.158(0.038)$ for target setting. The sub-set of 16 questions asked in an almost identical fashion to other sectors like manufacturing and healthcare (e.g. performance tracking, goal setting etc.) has a coefficient (standard error) of 0.248(0.045). We also looked at a subset of questions that are related to five practices examined in Dobbie and Fryer (2013) in New York charter schools - frequent teacher feedback, the use of data to guide instruction, high dosage tutoring, increased instructional time, and a culture of high 
expectations. ${ }^{28}$ We constructed a similar "Dobbie and Fryer" management index from our questions (data-driven planning and pupil transitions, adopting education best practices, personalization of instruction and learning, and clearly defined accountability for principals).

This coefficient (standard error) on this index is $0.134(0.038)$.

\section{HOW MANAGEMENT VARIES ACROSS SCHOOLS: THE ROLE OF AUTONOMOUS GOVERNMENT SCHOOLS}

\section{Empirical model of management}

Having established the presence of a positive correlation between our management practices score and school-level educational outcomes, we now turn to study how management varies within countries. We distinguish between three main types of schools: private schools, autonomous government schools and regular government schools. Recall that we define autonomous government schools as schools receiving at least partial funding from the government and with at least limited autonomy in one of three areas: establishing the curriculum content, selecting teachers, and admitting pupils. ${ }^{29}$ We use a simple regression model of the form:

$$
M_{i c}=\alpha^{\text {AUTOGOV }} \text { AUTGOV } i c+\alpha^{\text {PRIVATE }} \text { PRIVATE } i c+\alpha^{Z} X_{i c}+v_{i c}
$$

Given the differences between OECD and non-OECD countries we estimate separate equations for Brazil and India. Although we pool across OECD countries in the main specifications, we also consider disaggregating the OECD regressions by country (Appendix Table B5). Figure 5 shows management index differences across autonomous government, regular government and private schools in deviations from country means. On average across countries, private schools have the highest scores, followed by autonomous government schools and regular government schools at the bottom. There is much heterogeneity in the ranking across countries, however.

\footnotetext{
${ }^{28}$ Dobbie and Fryer (2013) show that this set of five practices are also strongly correlated with pupil achievement and explain approximately $45 \%$ of the variation in school effectiveness. In an experimental setting, Fryer (2014) shows that the average impact of implementing these policies significantly increases pupil math achievement in treated elementary and secondary schools by 0.15 to 0.18 standard deviations.

${ }^{29}$ Table 1 provides more details about schools under this classification across countries.
} 


\section{Main results on management}

Across OECD countries column (1) of Table 3 shows that autonomous government schools obtain significantly higher management scores than regular government schools (the omitted base category). The difference is large and significant: the management score of autonomous schools is 0.233 of a standard deviation higher relative to regular government schools, which amounts to about $13 \%$ of the gap in management between (say) the UK and India. Interestingly, the coefficient on private schools is negative suggesting that their higher pupil outcomes in earlier tables may be due to the type of pupils attending them. The base of the table has a test of the difference between autonomous government schools and private schools and finds this is significant across all specifications.

Clearly, differences in management may simply capture differences in observable characteristics across school types (Table B2 showed that school types differ across other dimensions beyond management). So in column (2) we augment the specification with the other covariates used in Table 2 together with "survey noise" controls, such as interviewer dummies. The coefficient on autonomous government schools slightly increases, suggesting that the managerial advantage of these schools is not mainly due to these factors. Similar to other sectors, size is significantly positively correlated with management scores. This might reflect the existence of economies of scale in management. It might also reflect the ability of better managed schools to attract more pupils, although this is less likely given that schools tend to have difficulty growing in most systems. ${ }^{30}$ Management is also significantly negatively correlated with the pupil/teacher ratio which may capture the fact that schools with higher resources may be able to establish and enforce better management processes (for example, when teachers are not as overstretched it might be easier to use merit based promotions, deal with underperformance etc. $\left.{ }^{31}\right)$.

Another possible explanation for the higher management score of autonomous government schools could be differences in location. For example, Angrist, Pathak, and Walters (2013) point out that while charter schools in urban areas have positive effects on pupil achievement, non-urban charter schools are on average ineffective and in some instances even detrimental

\footnotetext{
${ }^{30}$ Since private (and to a lesser extent autonomous government) schools have more ability to grow, we examined the reallocation story by looking at whether the association between management and size was stronger for these schools. We did not find systematic evidence of this, suggesting that the correlation may be more due to scale economies.

${ }^{31}$ Indeed, the negative correlation between management and the pupil/teacher ratio is much larger for the people management portion of the survey relative to the other non-people management questions.
} 
to pupils. To account for locational differences, we measure of population density in the area where the school is located in column (3). ${ }^{32} \mathrm{We}$ do find that schools in urban areas tend to have significantly higher managerial scores, but this only reduces the coefficient on autonomous government schools slightly (from 0.273 to 0.244 ). ${ }^{33}$

Appendix Table B5 explores the heterogeneity of the results across countries by estimating the same regression in column (3) of Table 3 separately for each of the OECD country in our sample. The coefficient on autonomous government schools is positive across all the countries in our sample, although it is especially large for Sweden which had the most radical institutional change towards autonomous government schools among our sampled countries. $^{34}$

In columns (4) to (6) of Table 3 we repeat the specifications for Brazil. We also find a positive managerial differential between autonomous government schools and regular government schools, although this result is based on only three autonomous government schools, thus difficult to generalize. ${ }^{35}$ In contrast with OECD countries, however, private schools in Brazil appear to have much higher scores relative to regular government schools. The private-regular government schools gap is substantial (about half a standard deviation), and is robust to the inclusion of measures of school size, curriculum offered and the ability to select pupils based on merit. Also in contrast with the OECD countries, the ability to select pupils on the basis of academic merit is positively correlated with management, while the proxy for regional density is not.

\footnotetext{
${ }^{32}$ Our measure of population density is at the NUTS 3 level for the OECD, at the municipality level for Brazil and at the sub-district level (Tehsils or Mandals) for India.

${ }^{33}$ The density variable is insignificant when included in the pupil performance regressions of column (3) of Table 2.

${ }^{34}$ The coefficient on the autonomous government schools dummy is very strong and significant in Sweden, and positive but not significant in Canada, Germany, UK, US. The coefficient on the dummy is still positive and significant at the $10 \%$ level when we pool all countries except Sweden. The Swedish case presents unique features as its education system benefited from a series of aggressive and rapid reforms in the early 1990s, starting with a decentralization of education to the municipal level, holding municipalities financially accountable for its schools and implementing a voucher program which led to a sharp increase in the number of friskolor and the number of pupils attending those schools (Sahlgren 2011). The US charter schools and the UK academies, on the other hand, were being progressively introduced at a much slower pace, starting in the mid- to the end of the 1990s. Studying the impact of the introduction of academies on pupil achievement, Machin and Vernoit (2011) find stronger positive results for schools that have been academies for longer and who have experienced the largest changes in governance practices, suggesting that the benefits of introducing autonomous government schools in an education system may take a while to materialize.

${ }^{35}$ In 2007, the state of Pernambuco partnered with a group of companies committed to improving education to convert 10 existing secondary schools into a new model of reference schools. By 2010, the program had expanded to 60 full-day and 100 half-day secondary schools (Bruns, Evans and Luque, 2012). By 2013, it reached a total of 260 schools.
} 
The final three columns of Table 3 repeat the specifications for India. The results substantially differ from the rest of the Table. Column (7) shows that private schools score on average higher in terms of management relative to regular government schools, while no significant difference can be found for autonomous government schools. However, the private-regular government differential is insignificant when we introduce basic controls for school size, pupil/teacher ratios and the ability to select pupils (many of the elite Indian government schools use such selection devices - e.g. Rao, 2014). This result suggests the better performance of private schools is likely due to greater resources which are particularly large in India and casts doubt on the idea that they are a possible solution to the chronic inefficiencies experienced in the public sector (e.g. OECD 2012).

In summary, autonomous government schools seem to have significantly better managerial scores than regular government schools in all countries except India. Private schools, by contrast, are no better than government schools in any country except Brazil, implying that their advantages in pupil performance in Table 2 are likely to be due to selection of pupils from wealthier families. ${ }^{36}$

\section{What explains the advantage of autonomous government schools?}

Our results indicate that autonomous government schools are fundamentally different in terms of the processes that they employ in the day-by-day management of these organizations. In Table 4 we explore what could account for the advantage of autonomous government schools focusing on OECD schools because of the differences we observed between the OECD countries and emerging economies. Column (1) reports the baseline specification of column (3) of Table 3. Column (2) includes a measure of competition to see if some schools are in areas where there is more pupil choice. ${ }^{37}$ The measure has a positive

\footnotetext{
${ }^{36}$ To account for potential differences between faith-based and non-faith-based schools, we introduce a dummy for faith-based schools in our sample to the full specifications in columns 3, 6, and 9. In each region the autonomous government school and the private school coefficients remain significant and nearly unchanged. In the OECD the autonomous government coefficient (standard error) changes to $0.235(0.075)$ and the private coefficient (standard error) changes to -0.019(0.094), in Brazil the autonomous government coefficient (standard error) changes to $0.894(0.182)$ and the private coefficient (standard error) changes to $0.465(0.096)$, and in India, the autonomous government and the private coefficient remain unchanged. In our sample, $14.2 \%$ of interviews in the OECD, $7.8 \%$ of interviews in Brazil and 15.7\% of interviews in India were run with principals of faithbased schools.

${ }^{37}$ Our measure of competition is collected during the survey itself by asking the principal "How many other schools offering education to 15 year-olds are within a 30-minute drive from your school?"
} 
but insignificant coefficient. ${ }^{38}$ Column (3) adds in some characteristics of the principal ${ }^{39}$ collected in the survey (tenure, gender and whether the principal has a background in STEM Science, Technology, Engineering, Maths, or Business). Of these only gender is significant: female principals are associated with higher management scores. But these covariates only reduce the autonomous government coefficient slightly. Column (4) includes three measures of the autonomy of the principal in terms of hiring and firing, budgetary expense and curriculum choices. Column (5) includes both the principal characteristics and autonomy measures. The autonomy measures are generally insignificant with the exception of personnel autonomy (which is significant at the 10\% level). Adding all six measures reduces the coefficient on the autonomous government dummies to 0.211 from 0.244 in column (1). So these measures of principal characteristics and autonomy do not really account for much of the difference.

So what does matter? We focus on two measures (see Appendix Table A2 for details): first; governance - the degree to which the principal is accountable to institutional stakeholders such as school external boards ("Principal Accountability"); and second, leadership - the degree to which the principal communicates a well-articulated strategy for the school over the next five years ("Principal Strategy"). Column (6) includes the Principal Accountability and the Principal Strategy variables, showing that these variables are highly significant and these two factors account for almost half of the gap between autonomous government and regular government schools (the coefficient falls from 0.211 to 0.129$).{ }^{40}$ Table B2 shows that, accountability and strategy are very different between school types. When we break the management questions into its two different subcomponents - people and non-people management -, we find that the dummy capturing principals with a STEM or Business background is correlated with non-people practices, that is, operations, monitoring and target setting, but not with people management, while the opposite holds for personnel autonomy.

\footnotetext{
${ }^{38}$ The evidence on the impact of competition and school choice is mixed. Some studies find a positive effect (Hoxby 2000; Card, Dooley, and Payne 2010; Gibbons, Machin, and Silva 2008; Ahlin 2003; Hanushek and Rivkin 2003) while other studies find a negative effect or no effect on pupil achievement (Hsieh and Urquiola 2006; Rothstein 2005).

${ }^{39}$ For instance, Clark, Martorell, and Rockoff (2009) find some evidence that experience as an assistant principal at the principal's current school is associated with higher performance among inexperienced principals. They also find a positive relationship between principal experience and school performance, particularly for math test scores and pupil absences.

${ }^{40}$ Both are about equally important. For example, just including accountability reduces the coefficient on autonomous government schools from 0.211 to 0.177 .
} 
Appendix Table B6 shows the results for India and Brazil. Overall, these are broadly consistent with those shown for OECD countries. In both Brazil and India, competition, principal characteristics and autonomy are not significantly correlated with the management score, while the accountability and strategy variables appear to be large in magnitude, and positively and significantly correlated with higher management scores. These findings suggest that governance and leadership may play an important role for the performance of schools even in developing economies.

\section{CONCLUSION}

Understanding the factors associated with variations in school performance within and across countries is important. While many researchers have looked at differences in school inputs such as teacher quality, class size and family/pupil characteristics - or variations in the institutional environment - such as pupil choice - few studies explore differences in school management. In this paper we show robust evidence that management practices vary significantly across and within countries and are strongly linked to pupil outcomes. Management quality seems to matter for schools.

A new finding is that autonomous government schools appear to have significantly higher management scores than both regular government schools and private schools. Their better performance is not linked with autonomy per se but with how autonomy is used. Having strong accountability of principals to an external governing body and exercising strong leadership through a coherent long-term strategy for the school appear to be two key features that account for a large fraction of the superior management performance of such schools.

From a policy point of view our findings suggest that improving management could be an important way of raising school standards and give broad support for the fostering of greater autonomy of government schools. Autonomy by itself is unlikely to deliver better results, however, finding ways to improve governance and motivate principals are likely to be key to make sure decentralized power leads to better standards.

Our work suggests many lines of future inquiry. First, we have only presented conditional correlations. Thinking of ways to evaluate the causal effects of management interventions such as randomized control trials (e.g. Fryer and Holden, 2014) is a high priority. Second, we only account for at most half of the better management of autonomous government schools 
with accountability and leadership: what else is important? Are there key characteristics of principals and teachers, for example, which we have missed out? Third, what drives improved school management? We have suggestive evidence that governance matters (as it does more widely in other sectors) but what about school networks, teacher skills, incentives, pupil choice and information? There is an exciting research agenda ahead.

\section{REFERENCES}

Abdulkadiroglu, Atila, Joshua D. Angrist, Susan M. Dynarski, Thomas J. Kane, and Parag A. Pathak. 2011. 'Accountability and Flexibility in Public Schools: Evidence from Boston's Charters And Pilots'. The Quarterly Journal of Economics 126 (2): 699-748

Ahlin, Åsa. 2003. 'Does School Competition Matter? Effects of a Large-Scale School Choice Reform on Student Performance'. Working Paper Series 2003:2. Uppsala University, Department of Economics.

Angrist, Joshua D., Susan M. Dynarski, Thomas J. Kane, Parag A. Pathak, and Christopher R. Walters. 2011. 'Who Benefits from KIPP?' IZA Discussion Paper 5690.

Angrist, Joshua D, Parag A Pathak, and Christopher R Walters. 2013. 'Explaining Charter School Effectiveness'. American Economic Journal: Applied Economics 5 (4): 1-27.

Béteille, Tara, Demetra Kalogrides, and Susanna Loeb. 2012. 'Stepping Stones: Principal Career Paths and School Outcomes'. Social Science Research 41 (4): 904-19.

Black, Sandra E., and Lisa M. Lynch. 2001. 'How to Compete: The Impact of Workplace Practices and Information Technology on Productivity'. The Review of Economics and Statistics 83 (3): 434-45.

Bloom, Nicholas, Christos Genakos, Raffaella Sadun, and John Van Reenen. 2012. 'Management Practices across Firms and Countries'. The Academy of Management Perspectives (AMP) 26 (1): 12-33.

Bloom, Nicholas, Tobias Kretschmer, and John Van Reenen. 2011. 'Are Family Friendly Workplace Practices a valuable firm resource?' Strategic Management Journal 32(4): 343-367.

Bloom, Nicholas, Carol Propper, Stephan Seiler, and John Van Reenen. (2015). 'The Impact of Competition on Management Quality: Evidence from Public Hospitals'. forthcoming Review of Economic Studies.

Bloom, Nicholas, and John Van Reenen. 2007. 'Measuring and Explaining Management Practices across Firms and Countries'. The Quarterly Journal of Economics 122 (4): 1351-1408.

—. 2010. 'Why Do Management Practices Differ across Firms and Countries?' Journal of Economic Perspectives 24 (1): 203-24.

Böhlmark, Anders, and Mikael Lindahl. 2012. 'Independent Schools and Long-Run Educational Outcomes: Evidence from Sweden's Large Scale Voucher Reform'. 6683. IZA Discussion Paper. Institute for the Study of Labor.

Branch, Gregory F., Eric A. Hanushek, and Steven G. Rivkin. 2012. 'Estimating the Effect of Leaders on Public Sector Productivity: The Case of School Principals'. Working Paper 17803. National Bureau of Economic Research.

Bruns, Barbara, Deon Filmer, and Harry Anthony Patrinos. 2011. Making Schools Work: New Evidence on Accountability Reforms. World Bank Publications. 
Bruns, Barbara, David Evans and Javier Luque. 2012. Achieving World-Class Education in Brazil: The Next Agenda. World Bank Publications.

Card, David, Martin D. Dooley, and A. Abigail Payne. 2010. 'School Competition and Efficiency with Publicly Funded Catholic Schools'. American Economic Journal: Applied Economics 2 (4): 150-76.

Clark, Damon. 2009. 'The Performance and Competitive Effects of School Autonomy'. Journal of Political Economy 117 (4): 745-83.

Clark, Damon, Paco Martorell, and Jonah E. Rockoff. 2009. 'School Principals and School Performance'. 38. CALDER Working Papers. Center for Analysis of Longitudinal Data in Education Research.

Coelli, Michael, and David A. Green. 2012. 'Leadership Effects: School Principals and Student Outcomes'. Economics of Education Review 31 (1): 92-109.

Curto, Vilsa E., and Roland G. Fryer. 2014. 'The Potential of Urban Boarding Schools for the Poor: Evidence from SEED'. Journal of Labor Economics, forthcoming.

Dhuey, Elizabeth, and Justin Smith. 2011. 'How Important Are School Principals in the Production of Student Achievement?' CLSSRN working paper clsrn_admin-2011-33. Vancouver School of Economics.

Di Liberto, Adriana, Fabiano Schivardi, and Giovanni Sulis. 2013. 'Managerial Practices and Students' Performance'. Universita Degli Studi Di Milano Mimeo, November.

Dobbie, Will, and Roland G. Fryer 2013. 'Getting Beneath the Veil of Effective Schools: Evidence from New York City'. American Economic Journal: Applied Economics 5(4): 28-60.

Dobbie, Will, and Roland G. Fryer 2011. 'Are High Quality Schools Enough to Close the Achievement Gap? Evidence from a Social Experiment in Harlem'. American Economic Journal: Applied Economics 3(3).

Duflo, Esther, Rema Hanna and Stephen P. Ryan. 2012. 'Incentives Work: Getting Teachers to Come to School'. American Economic Review 102(4): 1241-78

Eyles, Andrew and Stephen Machin (2014) "The Introduction of Academy Schools to England's Education", mimeo Centre for Economic Performance

Fryer, Roland G. and Richard Holden. 2012. "Multitasking, Learning, and Incentives: A Cautionary Tale". Working Paper 17752. National Bureau of Economic Research.

Fryer, Roland G. 2014. 'Injecting Charter School Best Practices into Traditional Public Schools: Evidence from Field Experiments. Quarterly Journal of Economics, forthcoming.

Fuchs, Thomas, and Ludger Woessmann. 2007. 'What Accounts for International Differences in Student Performance? A Re-Examination Using PISA Data'. Empirical Economics 32 (2-3): 433-64.

Gibbons, Stephen, Stephen Machin, and Olmo Silva. 2008. 'Choice, Competition, and Pupil Achievement'. Journal of the European Economic Association 6 (4): 912-47.

Grissom, Jason A., and Susanna Loeb. 2011. 'Triangulating Principal Effectiveness How Perspectives of Parents, Teachers, and Assistant Principals Identify the Central Importance of Managerial Skills'. American Educational Research Journal 48(5):1091-1123.

Hanushek, Eric. A, and Ludger Woessmann. 2010. 'The Economics of International Differences in Educational Achievement'. Working Paper 15949. National Bureau of Economic Research.

Hanushek, Eric A. 1979. 'Conceptual and Empirical Issues in the Estimation of Educational Production Functions'. The Journal of Human Resources 14 (3): 351-88.

Hanushek, Eric A., and Steven G. Rivkin. 2003. 'Does Public School Competition Affect Teacher Quality?' in The Economics of School Choice: 23-48. National Bureau of Economic Research. 
Hanushek, Eric A., Susanne Link, and Ludger Woessmann. 2013. 'Does School Autonomy Make Sense Everywhere? Panel Estimates from PISA'. Journal of Development Economics 104 (September): 212-32.

Horng, Eileen Lai, Daniel Klasik, and Susanna Loeb. 2010. 'Principal's Time Use and School Effectiveness'. American Journal of Education 116 (4): 491-523.

Hoxby, Caroline M. 2000. 'Does Competition among Public Schools Benefit Students and Taxpayers?' The American Economic Review 90 (5): 1209-38.

Hoxby, Caroline M., and Sonali Murarka. 2009. 'Charter Schools in New York City: Who Enrolls and How They Affect Their Students' Achievement'. Working Paper 14852. National Bureau of Economic Research.

Hsieh, Chang-Tai, and Miguel Urquiola. 2006. 'The Effects of Generalized School Choice on Achievement and Stratification: Evidence from Chile's Voucher Program'. Journal of Public Economics 90 (8-9): 1477-1503.

Ichniowski, Casey, Kathryn Shaw, and Giovanna Prennushi. 1997. 'The Effects of Human Resource Management Practices on Productivity: A Study of Steel Finishing Lines'. American Economic Review 87 (3): 291-313.

Lavy, Victor. 2010. 'Do Differences in School's Instruction Time Explain International Achievement Gaps in Math, Science, and Reading? Evidence from Developed and Developing Countries'. Working Paper 16227. National Bureau of Economic Research.

Machin, Stephen, and James Vernoit. 2011. 'Changing School Autonomy: Academy Schools and Their Introduction to England's Education'. Working Paper 123. Centre for the Economics of Education .

McCormack, John, Carol Propper, and Sarah Smith. 2014. 'Herding Cats? Management and University Performance'. The Economic Journal 124 (578): 534-564.

OECD. 2012. Public and Private Schools: How Management and Funding Relate to Their Socio-Economic Profile. Paris: OECD Publishing.

Rao, Gautam. 2014. 'Familiarity Does Not Breed Contempt: Generosity, Discrimination and Diversity in Delhi Schools'. UC Berkeley Mimeo.

Rasul, Imran, and Daniel Rogger. 2013. 'Management of Bureaucrats and Public Service Delivery: Evidence from the Nigerian Civil Service'. UCL Mimeo.

Rothstein, Jesse. 2005. 'Does Competition among Public Schools Benefit Students and Taxpayers? A Comment on Hoxby (2000)'. Working Paper 11215. National Bureau of Economic Research.

Sahlgren, Gabriel H. 2011. 'Schooling for Money: Swedish Education Reform and the Role of the Profit Motive'. Economic Affairs 31 (3): 28-35.

Warren, John Robert, Krista N. Jenkins, and Rachael B. Kulick. 2006. 'High School Exit Examinations and State-Level Completion and GED Rates, 1975 through 2002.' Educational Evaluation and Policy Analysis 28 (2): 131-152.

Woessmann, Ludger. 2003. 'Central Exams as the "Currency" of School Systems: International Evidence on the Complementarity of School Autonomy and Central Exams'. CESifo DICE Report 1 (4): 46-56.

- 2005. 'The Effect Heterogeneity of Central Examinations: Evidence from TIMSS, TIMSS-Repeat and PISA'. Education Economics 13 (2): 143-69.

- 2010. 'Cross-Country Evidence on Teacher Performance Pay'. CESifo Working Paper Series 3151. CESifo Group Munich.

Woessmann, Ludger, Elke Lüdemann, Gabriela Schütz, and Martin R. West. 2007. 'School Accountability, Autonomy, Choice, and the Level of Student Achievement'. OECD Education Working Papers 13. Paris: OECD Publishing. 
FIGURE 1: AVERAGE MANAGEMENT SCORE BY COUNTRY

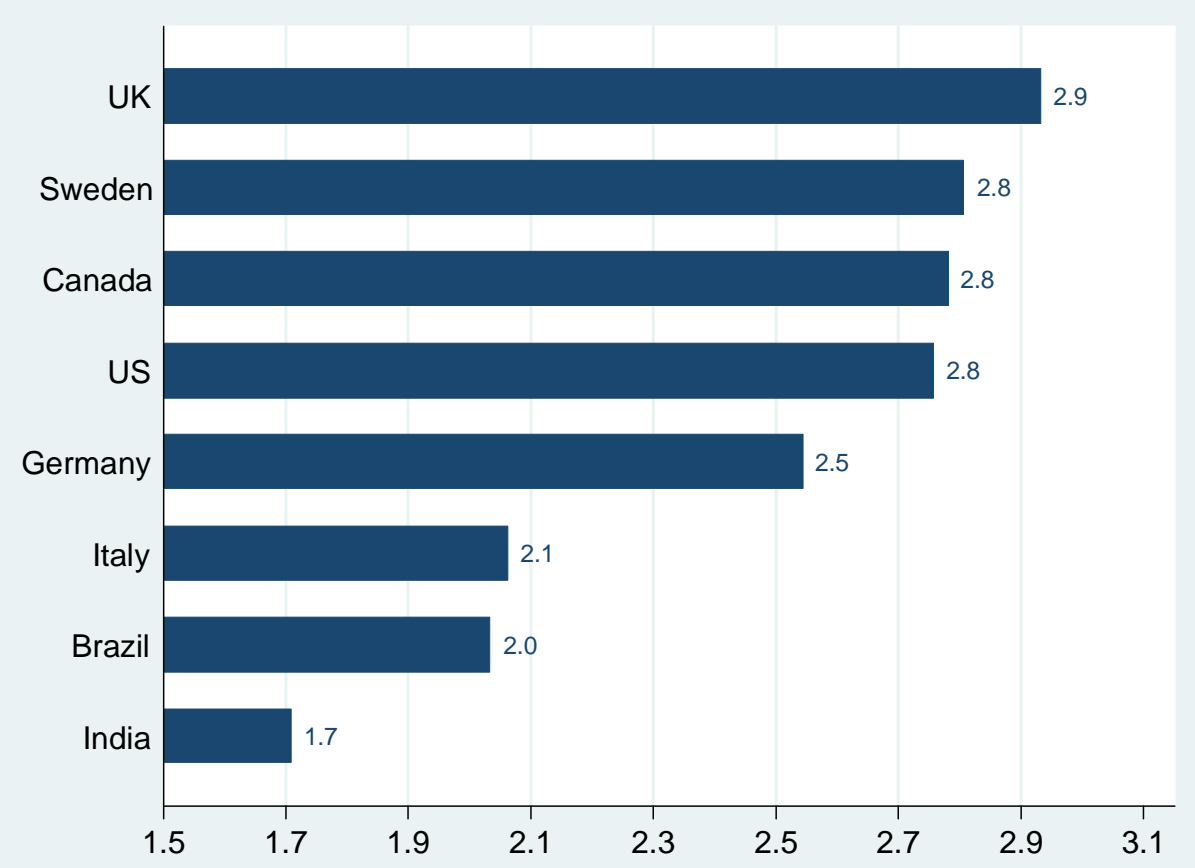

Notes: Data from 1,851 schools. 513 in Brazil; 146 in Canada; 140 in Germany, 318 in India, 284 in Italy, 88 in Sweden, 92 in the UK and 270 in the US. A school level score is the simple average across all 20 questions and the country average (shown above) is the unweighted average of these school level scores within a country.

\section{FIGURE 2: PEOPLE AND NON-PEOPLE MANAGEMENT BY COUNTRY}

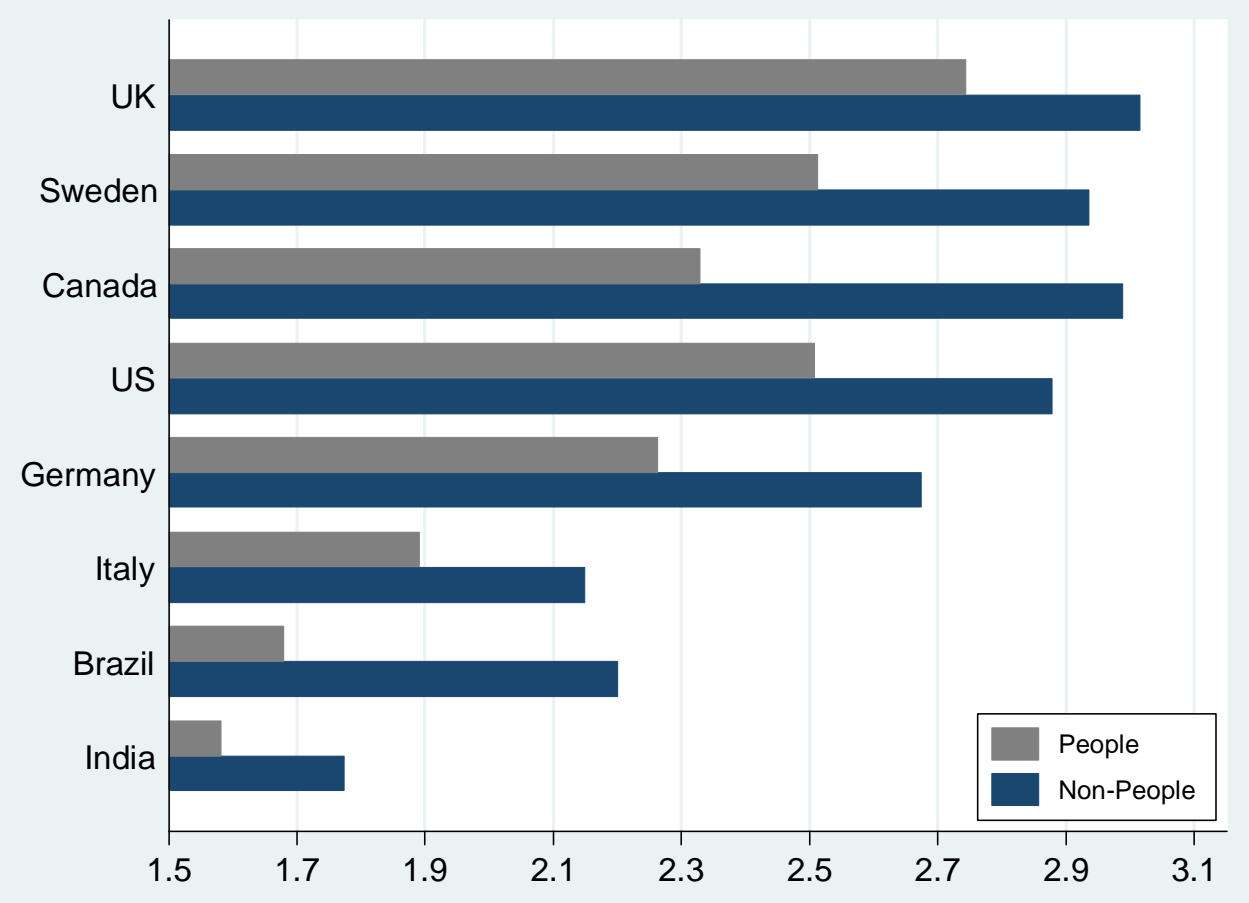

Notes: Country-level averages for people management vs. non-people management practices. Broadly speaking people management involves pay, promotions, hiring and firing, while non-people involves school operations, monitoring and targets (see Table A1 for the precise definitions). 


\section{FIGURE 3: MANAGEMENT WITHIN COUNTRIES}
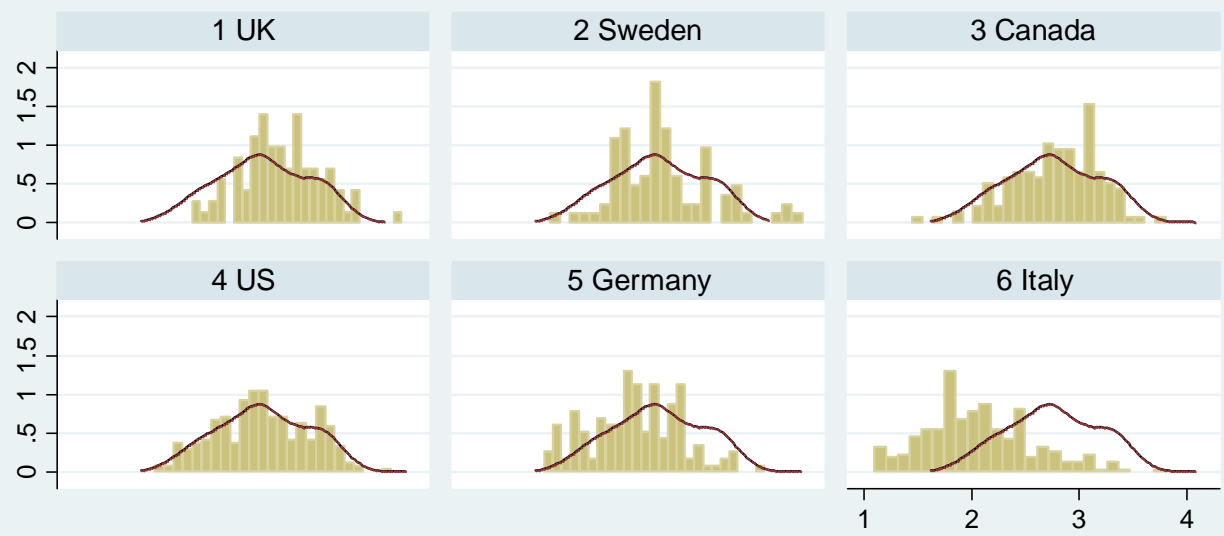

7 Brazil

8 India
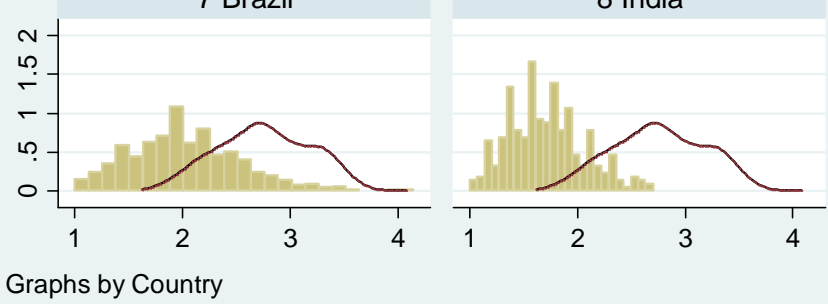

Notes: Data from 1,851 schools showing the distribution of the firm level school scores. A smoothed kernel density plot of the US data is shown on each panel for easy comparison to the US management distribution.

\section{FIGURE 4: COMPARING THE DISTRIBUTION OF MANAGEMENT IN SCHOOLS, HOSPITALS AND MANUFACTURING FIRMS IN THE US AND UK}

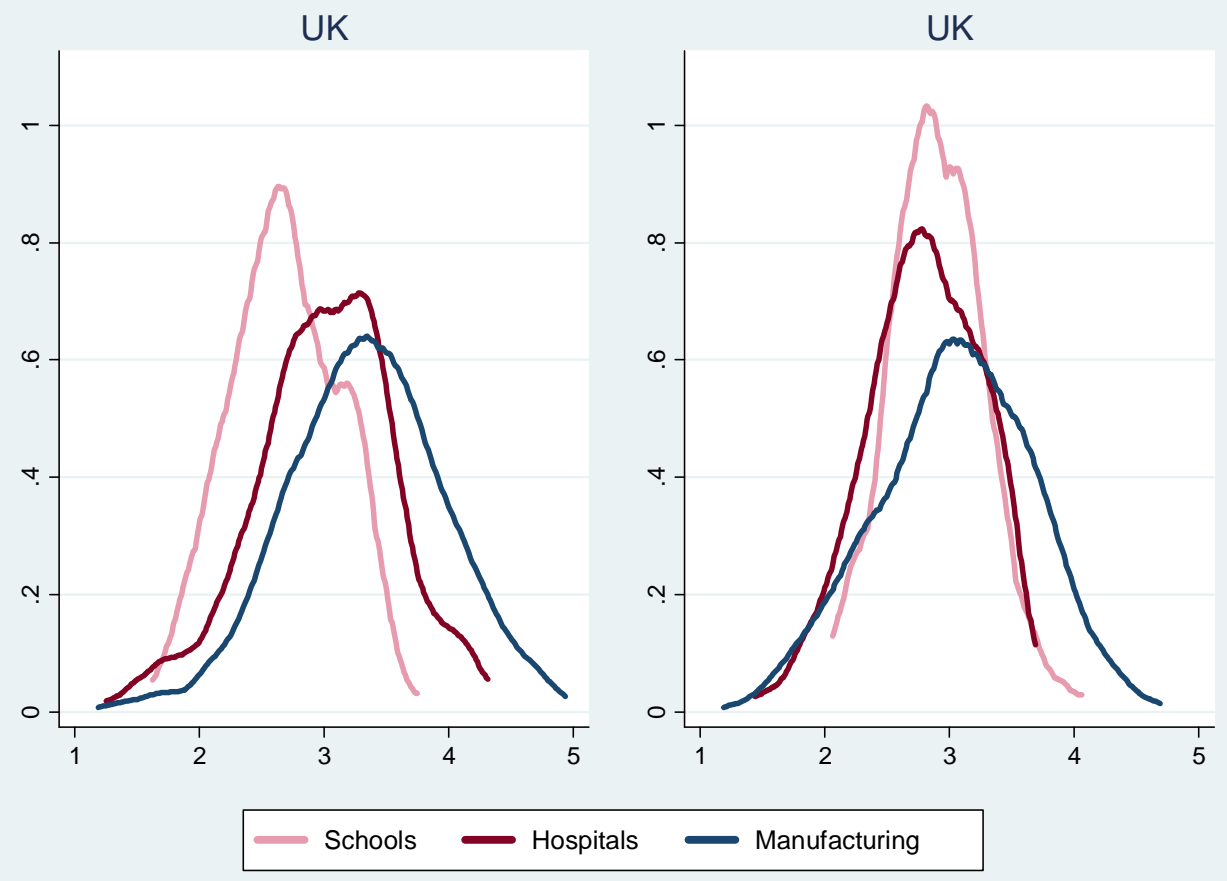

Notes: The management index is constructed from the 16 questions that overlap in all three sectors. Smoothed kernel density shown for each sector. 
FIGURE 5: MANAGEMENT INDEX DIFFERENCES ACROSS SCHOOL TYPES DEVIATIONS FROM COUNTRY MEANS

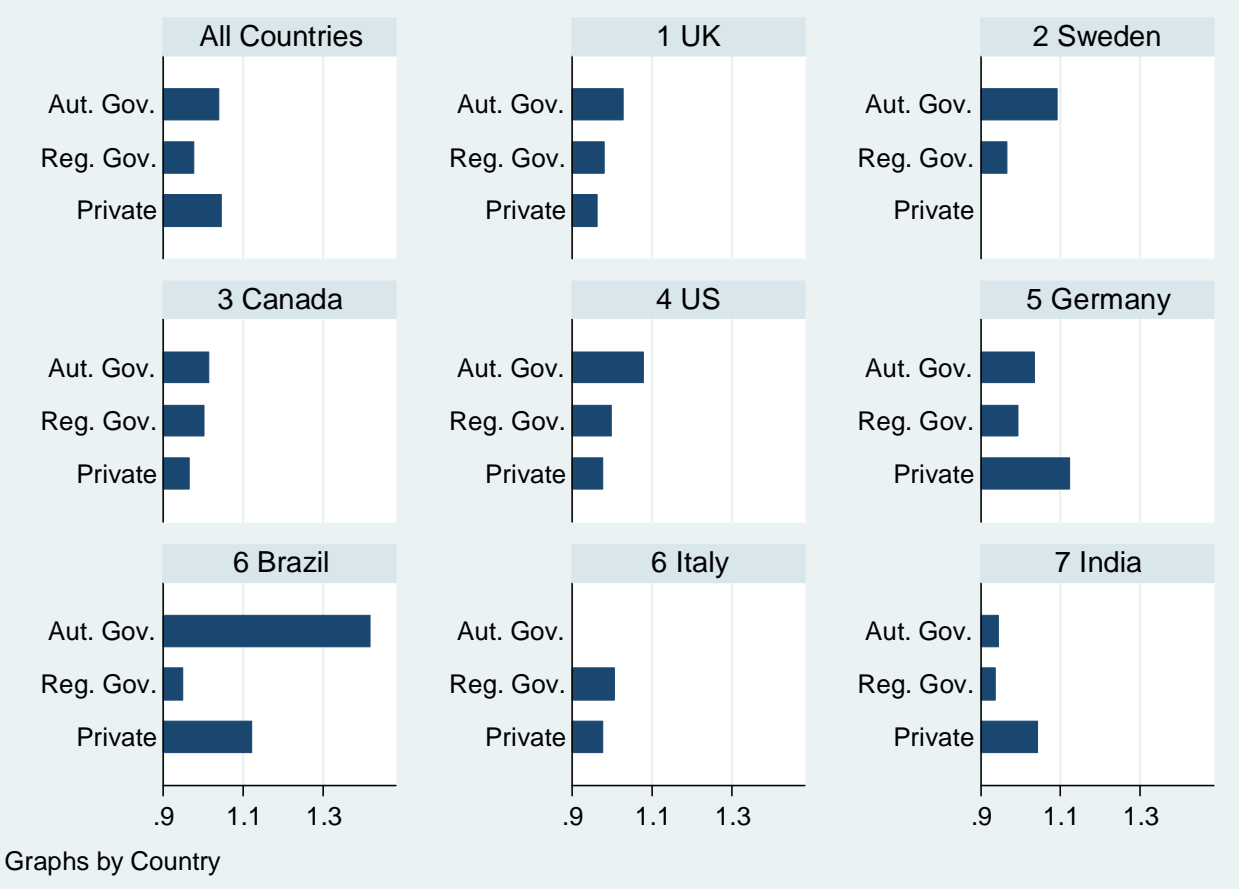

Notes: Data from 1,567 schools. 513 in Brazil; 146 in Canada; 140 in Germany, 318 in India, 88 in Sweden, 92 in the UK and 270 in the US. "Aut. Gov." are autonomous government schools, "Reg. Gov." are regular government schools and "Private" are private schools. There are no autonomous government schools in Italy. 
TABLE 1: CLASSIFICATION OF AUTONOMOUS GOVERNMENT SCHOOLS

\begin{tabular}{lllll}
\hline \hline School Type & $\begin{array}{l}\text { Government } \\
\text { Funding }\end{array}$ & $\begin{array}{l}\text { Curriculum } \\
\text { Autonomy }\end{array}$ & $\begin{array}{l}\text { Teacher } \\
\text { Selection } \\
\text { Autonomy }\end{array}$ & $\begin{array}{l}\text { Pupil } \\
\text { Admissions } \\
\text { Autonomy }\end{array}$ \\
\hline $\begin{array}{l}\text { Escolas de Referência, Brazil } \\
\text { Separate Schools, Canada }\end{array}$ & Most (1) & Limited & Limited & None \\
$\begin{array}{l}\text { Private Ersatzschulen, Germany } \\
\text { Private Aided Schools, India }\end{array}$ & All (2) & Limited (4) & Full & Full \\
Friskolor, Sweden & Most (3) & None & None & Limited (15) \\
Academy Schools, UK & Most (3) & Limited (6) & Full & None \\
Foundation Schools, UK & All & Limited (7) & Limited (12) & Limited (17) \\
Voluntary Aided Schools, UK & All & Limited (8) & Limited (13) & Limited (18) \\
Charter Schools, US & Most (3) & Limited (9) & Full & None \\
Magnet Schools, US & All & Limited (10) & None & Limited (19) \\
\hline \hline
\end{tabular}

Notes: The Brazilian Escolas de Referência are found in Pernambuco State only. The Canadian Separate Schools are found in Alberta, Ontario, and Saskatchewan only. The following explanations refer to when Limited Autonomy is granted to autonomous government schools in these three areas plus funding. (1) The state government is responsible for staff salaries, school feeding, books, and uniforms, and private funding finances infrastructure investments and scholarships for low-income pupils. (2) Government funding can be anywhere from $90 \%$ to $100 \%$, the remaining can be from private sources. (3) May receive private donations. (4) Catholic concepts and values determine the orientation of the standard curriculum's content. (5) Curriculum must have at least the same academic standards as government schools. (6) Follow the National Curriculum but with a particular focus on one or more areas. (7) May partner up with organisations to bring specific skills and expertise to the school. (8) Religious education may be taught according to a specific faith. (9) Must meet federal and state standards but innovation in the curriculum design and structure is permitted. (10) Must cover a set of core academic subjects, but may concentrate on a particular discipline or area of study. (11) Teachers must have at least the same education and earn at least the same wages as teachers in regular government schools. (12) Local Education Authority will appoint Head Teacher from candidates shortlisted by school. (13) Local Education Authority must be involved in the selection process. (14) No segregation of pupils according to the means of their parents. (15) Conditional on the amount of funding received by the government. (16) May choose up to $10 \%$ of pupils based on aptitude. (17) Cannot operate admissions outside the LEA's coordinated admissions scheme. (18) Must consult other admissions authorities as well as their Diocesan Directors of Education when there are substantial changes. The school can use faith criteria in prioritising pupils for admission. (19) Most have no entrance criteria but some are highly selective. 
TABLE 2: PUPIL OUTCOMES AND MANAGEMENT

\begin{tabular}{|c|c|c|c|c|c|c|c|c|c|c|}
\hline & (1) & (2) & (3) & (4) & (5) & (6) & (7) & (8) & (9) & (10) \\
\hline Sample of countries: & All & All & All & Brazil & Canada & India & Sweden & US & UK & UK \\
\hline Dependent variable: & \multicolumn{3}{|c|}{$\begin{array}{c}\text { Cross-country pooled pupil } \\
\text { achievement }\end{array}$} & $\begin{array}{l}\text { Math } \\
\text { Average }\end{array}$ & $\begin{array}{l}\text { Fraser } \\
\text { Rating }\end{array}$ & $\begin{array}{l}\text { Average } \\
\text { Math }\end{array}$ & $\begin{array}{l}\text { 9th grade } \\
\text { GPA }\end{array}$ & $\begin{array}{l}\text { HSEE } \\
\text { Math } \\
\text { Pass }\end{array}$ & $\begin{array}{l}\text { Average } \\
\text { GCSE }\end{array}$ & $\begin{array}{l}\text { Context. } \\
\text { Value } \\
\text { Added }\end{array}$ \\
\hline \multirow[t]{2}{*}{ Management (z-score) } & $0.425 * * *$ & $0.242 * * *$ & $0.232 * * *$ & $0.104 * *$ & 0.609 & $0.499 * *$ & 0.242 & $0.170^{* *}$ & $0.512 *$ & $0.881 * *$ \\
\hline & $(0.046)$ & $(0.041)$ & $(0.044)$ & $(0.050)$ & $(0.368)$ & $(0.243)$ & $(0.206)$ & $(0.080)$ & $(0.272)$ & $(0.369)$ \\
\hline \multirow{2}{*}{$\begin{array}{l}\text { Autonomous government } \\
\text { school }\end{array}$} & & $0.225^{*}$ & $0.396 * * *$ & 0.235 & -0.263 & 0.211 & $0.612 * *$ & 0.123 & 0.245 & -0.309 \\
\hline & & $(0.129)$ & $(0.114)$ & $(0.289)$ & $(0.467)$ & $(0.216)$ & $(0.291)$ & $(0.229)$ & $(0.319)$ & $(0.428)$ \\
\hline \multirow[t]{2}{*}{ Private school } & & $1.246 * * *$ & $1.139 * * *$ & $1.496^{* * *}$ & 0.937 & $0.383 *$ & & & -0.633 & \\
\hline & & $(0.081)$ & $(0.094)$ & $(0.101)$ & $(0.585)$ & $(0.208)$ & & & (1.014) & \\
\hline \multirow{2}{*}{ Log(pupils) } & & & $0.075 *$ & $0.126^{* *}$ & $0.396^{*}$ & 0.001 & 0.352 & $0.206^{* *}$ & -0.620 & -0.566 \\
\hline & & & $(0.042)$ & $(0.060)$ & $(0.213)$ & $(0.136)$ & $(0.262)$ & $(0.103)$ & $(0.441)$ & $(0.610)$ \\
\hline \multirow[t]{2}{*}{ Log(pupils/teachers) } & & & -0.014 & -0.118 & -0.473 & 0.087 & -0.103 & -0.486 & 0.456 & 0.424 \\
\hline & & & $(0.086)$ & $(0.109)$ & $(0.615)$ & $(0.188)$ & $(0.261)$ & $(0.471)$ & $(0.864)$ & $(2.426)$ \\
\hline \multirow{2}{*}{$\begin{array}{l}\text { Pupils selected on academic } \\
\text { merit }\end{array}$} & & & $0.477 * * *$ & $0.526 * * *$ & 0.588 & 0.048 & $2.368 * * *$ & $0.743 * *$ & $1.145 * * *$ & -0.260 \\
\hline & & & $(0.109)$ & $(0.151)$ & $(0.488)$ & $(0.188)$ & $(0.496)$ & $(0.340)$ & $(0.400)$ & $(0.582)$ \\
\hline General controls & No & No & Yes & Yes & Yes & Yes & Yes & Yes & Yes & Yes \\
\hline Pupil controls (cty-specific) & No & No & No & Yes & Yes & Yes & Yes & Yes & Yes & Yes \\
\hline Observations & 1,002 & 1,002 & 1,002 & 472 & 77 & 152 & 82 & 133 & 86 & 78 \\
\hline Dependent variables (mean) & & & & 514.20 & 5.92 & 69.23 & 211.53 & 69.96 & 442.78 & 1002.81 \\
\hline
\end{tabular}

Notes: Significance at the $1 \%$ level denoted by $* * *$ and $* *$ for $5 \%$ and $* 10 \%$ level. OLS estimates with robust standard errors in parentheses under coefficients. For the cross-country pooled measure, we use the math exam pass rate from HSEEs in US (government schools only), uncapped GCSE score in UK, Fraser Institute school rating in Canada, 9th grade GPA in Sweden, average math score in High School National Exam (ENEM) in Brazil, average math score in X Standards in India. In the UK we also use a contextual value added measure (see Appendix A for details). Pupil achievement data z-scored within country. Autonomous government schools are escolas de referência in Brazil, separate schools in Canada, private ersatzschulen in Germany, private-aided schools in India, friskolor in Sweden, academies, foundation, and voluntary-aided schools in the UK, and charter and magnet schools in the US. Management is z-score of the averaged of the z-scored 20 individual questions. All regressions have country dummies. General controls: regional dummies, school curriculum (academic vs. vocational) and noise (job post and tenure of interviewee; interviewer dummies, day of week; time of day and interview duration and reliability measure). Pupil controls: Brazil (\% of female pupils, \% of foreign and naturalized pupils, and $\%$ of indigenous pupils), Canada (\% of pupils whose 1 st language is known/believed to be other than English), India (\% of female pupils and $\%$ of pupils who are native speakers of the local language),Sweden (\% of female pupils and \% of pupils whose 1 st language is Swedish in Sweden), UK (\% of female pupils, $\%$ of pupils whose 1st language is not English, \% of non-white pupils, and \% of pupils eligible for a school meal); and US (\% of female pupils, \% of non-white pupils, and \% of pupils eligible for a school meal). 
TABLE 3: MANAGEMENT REGRESSIONS - ACCOUNTING FOR DIFFERENCES BETWEEN SCHOOL TYPES

\begin{tabular}{|c|c|c|c|c|c|c|c|c|c|}
\hline \multirow{3}{*}{$\begin{array}{l}\text { Dependent variable: } \\
\text { Country sample: }\end{array}$} & (1) & (2) & (3) & (4) & (5) & (6) & (7) & (8) & (9) \\
\hline & \multicolumn{9}{|c|}{ Management } \\
\hline & OECD & OECD & OECD & Brazil & Brazil & Brazil & India & India & India \\
\hline \multirow[t]{2}{*}{ Autonomous government school } & $0.233 * * *$ & $0.273 * * *$ & $0.244 * * *$ & $1.790 * * *$ & $0.926 * * *$ & $0.893 * * *$ & -0.013 & 0.006 & 0.002 \\
\hline & $(0.086)$ & $(0.076)$ & $(0.075)$ & $(0.088)$ & $(0.179)$ & $(0.181)$ & $(0.150)$ & $(0.107)$ & $(0.110)$ \\
\hline \multirow[t]{2}{*}{ Private school } & $-0.149 *$ & 0.033 & -0.004 & $0.504 * * *$ & $0.457 * * *$ & $0.471 * * *$ & $0.273 * * *$ & 0.015 & 0.008 \\
\hline & $(0.078)$ & $(0.071)$ & $(0.076)$ & $(0.089)$ & $(0.083)$ & $(0.082)$ & $(0.074)$ & $(0.067)$ & $(0.069)$ \\
\hline Log(pupils) & & $(0.032)$ & $(0.033)$ & & $(0.055)$ & $(0.058)$ & & $(0.040)$ & $(0.041)$ \\
\hline \multirow[t]{2}{*}{ Log(pupils/teachers) } & & $-0.163 * *$ & $-0.150 * *$ & & -0.066 & -0.079 & & $-0.291 * * *$ & $-0.288 * * *$ \\
\hline & & $(0.070)$ & $(0.070)$ & & $(0.102)$ & $(0.103)$ & & $(0.063)$ & $(0.063)$ \\
\hline Pupils selected on academic & & 0.038 & 0.034 & & $0.345 * *$ & $0.366^{* *}$ & & $0.232 * * *$ & $0.230 * * *$ \\
\hline merits & & $(0.088)$ & $(0.087)$ & & $(0.141)$ & $(0.144)$ & & $(0.055)$ & $(0.056)$ \\
\hline Regular (non-vocational) & & $0.170 * *$ & $0.165 * *$ & & 0.114 & 0.133 & & & \\
\hline \multirow[t]{2}{*}{ Log(population density) } & & & $0.057 * * *$ & & & -0.059 & & & 0.012 \\
\hline & & & $(0.018)$ & & & $(0.041)$ & & & $(0.024)$ \\
\hline Noise controls & No & Yes & Yes & No & Yes & Yes & No & Yes & Yes \\
\hline Test Private=Aut. gov. (p-value) & 0.000 & 0.014 & 0.012 & 0.000 & 0.020 & 0.040 & 0.070 & 0.937 & 0.959 \\
\hline Observations & 1,020 & 1,020 & 1,020 & 513 & 513 & 318 & 318 & 318 & 318 \\
\hline
\end{tabular}

Notes: Significance at the $1 \%$ level denoted by $* * *$ and $* *$ for $5 \%$ and $* 10 \%$ level. OLS estimates with robust standard errors in parentheses under coefficients. All columns have country and regional controls. The Management variable takes the average of all 20 management questions. Autonomous government schools are separate schools in Canada, private ersatzschulen in Germany, friskolor in Sweden, academies, foundation, and voluntary-aided schools in the UK; charter and magnet schools in the US; escolas de referência in Brazil; private-aided schools in India. Population density is at the NUTS3 level. Noise controls include 23 interviewer dummies, day of week; time of day interview conducted, interview duration, reliability measure, and job post of interviewee. 
TABLE 4: ACCOUNTING FOR THE ADVANTAGE OF AUTONOMOUS GOVERNMENT SCHOOLS IN THE OECD

\begin{tabular}{|c|c|c|c|c|c|c|c|c|}
\hline & (1) & (2) & (3) & (4) & (5) & (6) & (7) & (8) \\
\hline Dependent Variable & \multicolumn{6}{|c|}{ Management } & Non-People & People \\
\hline Autonomous government school & $\begin{array}{c}0.244 * * * \\
(0.075)\end{array}$ & $\begin{array}{c}0.244 * * * \\
(0.075)\end{array}$ & $\begin{array}{c}0.233 * * * \\
(0.074)\end{array}$ & $\begin{array}{c}0.223 * * * \\
(0.076)\end{array}$ & $\begin{array}{c}0.211 * * * \\
(0.075)\end{array}$ & $\begin{array}{c}0.129 * * \\
(0.060)\end{array}$ & $\begin{array}{c}0.050 \\
(0.061)\end{array}$ & $\begin{array}{c}0.296 * * * \\
(0.083)\end{array}$ \\
\hline Private school & $\begin{array}{c}-0.004 \\
(0.076)\end{array}$ & $\begin{array}{c}-0.006 \\
(0.077)\end{array}$ & $\begin{array}{c}0.013 \\
(0.076)\end{array}$ & $\begin{array}{c}-0.061 \\
(0.082)\end{array}$ & $\begin{array}{c}-0.058 \\
(0.083)\end{array}$ & $\begin{array}{c}-0.049 \\
(0.070)\end{array}$ & $\begin{array}{c}-0.193 * * * \\
(0.074)\end{array}$ & $\begin{array}{c}0.337 * * * \\
(0.092)\end{array}$ \\
\hline Log(pupils) & $\begin{array}{c}0.113 * * * \\
(0.033)\end{array}$ & $\begin{array}{c}0.112 * * * \\
(0.033)\end{array}$ & $\begin{array}{c}0.115^{* * * *} \\
(0.033)\end{array}$ & $\begin{array}{c}0.118^{* * *} \\
(0.033)\end{array}$ & $\begin{array}{c}0.120 * * * \\
(0.034)\end{array}$ & $\begin{array}{c}0.070 * * \\
(0.029)\end{array}$ & $\begin{array}{c}0.043 \\
(0.030)\end{array}$ & $\begin{array}{c}0.123 * * * \\
(0.037)\end{array}$ \\
\hline Log(pupils/teachers) & $\begin{array}{c}-0.150 * * \\
(0.070)\end{array}$ & $\begin{array}{c}-0.151 * * \\
(0.070)\end{array}$ & $\begin{array}{c}-0.151 * * \\
(0.071)\end{array}$ & $\begin{array}{c}-0.158 * * \\
(0.070)\end{array}$ & $\begin{array}{c}-0.163^{* *} \\
(0.072)\end{array}$ & $\begin{array}{c}-0.108 * \\
(0.063)\end{array}$ & $\begin{array}{l}-0.035 \\
(0.063)\end{array}$ & $\begin{array}{c}-0.252^{* * *} \\
(0.080)\end{array}$ \\
\hline Competition & & $\begin{array}{c}0.007 \\
(0.039)\end{array}$ & & & $\begin{array}{c}0.021 \\
(0.038)\end{array}$ & $\begin{array}{l}-0.006 \\
(0.034)\end{array}$ & $\begin{array}{l}-0.013 \\
(0.036)\end{array}$ & $\begin{array}{c}0.015 \\
(0.040)\end{array}$ \\
\hline Principal tenure (years) & & & $\begin{array}{c}-0.004 \\
(0.003)\end{array}$ & & $\begin{array}{c}-0.004 \\
(0.003)\end{array}$ & $\begin{array}{c}-0.004 \\
(0.003)\end{array}$ & $\begin{array}{c}-0.003 \\
(0.003)\end{array}$ & $\begin{array}{c}-0.004 \\
(0.004)\end{array}$ \\
\hline Principal gender (male) & & & $\begin{array}{c}-0.134 * * * \\
(0.041)\end{array}$ & & $\begin{array}{c}-0.142 * * * \\
(0.041)\end{array}$ & $\begin{array}{c}-0.097 * * * \\
(0.036)\end{array}$ & $\begin{array}{c}-0.108 * * * \\
(0.038)\end{array}$ & $\begin{array}{l}-0.066 \\
(0.044)\end{array}$ \\
\hline Principal has STEM background & & & $\begin{array}{c}0.070 \\
(0.046)\end{array}$ & & $\begin{array}{c}0.072 \\
(0.046)\end{array}$ & $\begin{array}{c}0.059 \\
(0.041)\end{array}$ & $\begin{array}{l}0.077 * \\
(0.042)\end{array}$ & $\begin{array}{c}0.012 \\
(0.049)\end{array}$ \\
\hline Principal personnel autonomy & & & & $\begin{array}{c}0.059 \\
(0.037)\end{array}$ & $\begin{array}{l}0.065 * \\
(0.037)\end{array}$ & $\begin{array}{c}0.060 * \\
(0.032)\end{array}$ & $\begin{array}{c}0.026 \\
(0.032)\end{array}$ & $\begin{array}{c}0.131 * * * \\
(0.038)\end{array}$ \\
\hline Principal budgetary autonomy & & & & $\begin{array}{c}0.003 \\
(0.029)\end{array}$ & $\begin{array}{c}0.005 \\
(0.029)\end{array}$ & $\begin{array}{c}0.007 \\
(0.025)\end{array}$ & $\begin{array}{c}0.003 \\
(0.026)\end{array}$ & $\begin{array}{c}0.015 \\
(0.030)\end{array}$ \\
\hline Principal academic content autonomy & & & & $\begin{array}{c}-0.004 \\
(0.031)\end{array}$ & $\begin{array}{c}-0.004 \\
(0.031)\end{array}$ & $\begin{array}{c}-0.015 \\
(0.028)\end{array}$ & $\begin{array}{c}-0.019 \\
(0.028)\end{array}$ & $\begin{array}{c}0.002 \\
(0.032)\end{array}$ \\
\hline Principal accountability & & & & & & $\begin{array}{c}0.235^{* * *} * \\
(0.022)\end{array}$ & $\begin{array}{c}0.234 * * * \\
(0.023)\end{array}$ & $\begin{array}{c}0.184 * * * \\
(0.029)\end{array}$ \\
\hline Principal strategy & & & & & & $\begin{array}{c}0.236^{* * *} \\
(0.023)\end{array}$ & $\begin{array}{c}0.251 * * * \\
(0.024)\end{array}$ & $\begin{array}{c}0.161 * * * \\
(0.026)\end{array}$ \\
\hline Test Private $=$ Aut. gov. (p-value $)$ & 0.012 & 0.012 & 0.023 & 0.005 & 0.008 & 0.046 & 0.006 & 0.679 \\
\hline
\end{tabular}

Notes: All columns have 1,020 observations. Significance at the $1 \%$ level denoted by $* * *$ and $* *$ for $5 \%$ and $* 10 \%$ level. OLS estimates with robust standard errors in parentheses under coefficients. All columns contain country dummies, regional dummies, population density, whether regular academic curriculum, whether pupils selected on academic merit and noise controls. The Management variable takes the average of all 20 management questions. Autonomous government schools are separate schools in 


\section{ONLINE APPENDICES: NOT INTENDED FOR PUBLICATION UNLESS REQUESTED BY \\ REFEREES}

\section{APPENDIX A: DATA}

\section{A1. Management Survey Data}

Table A1 lists the 20 management practices questions asked during the survey. The questions on accountability and strategy are in Table A2 and on autonomy in Table A3.

\section{A2. School-Level Pupil Outcome Data}

We use school performance data for all countries surveyed, except Germany for which data is not available at the time and for Italy for which a companion paper has been written (Di Liberto, Schivardi, and Sulis 2013). Across all other countries we have found two types of school performance data: 1) standardized (and sometimes compulsory) examination results and 2) non-standardized examination results. Below is a description of our school performance dataset for each country.

\section{Performance data for countries with a standardized examination system across regions}

\section{Brazil}

For Brazilian schools, our main performance indicator is the 2011 overall school math average in the Exame Nacional do Ensino Médio (ENEM), a non-mandatory national exam often used as a secondary school pupil evaluation (and award certification for secondary school degree) and/or as a standard university entrance qualification test. The exam is administered by the Instituto Nacional de Estudos e Pesquisas Educacionais (INEP). The ENEM consists of 180 multiple-choice questions equally divided into four subject areas - math (math and geometry), natural sciences (biology, physics and chemistry), human sciences (history, geography, philosophy and sociology), languages and codes (Portuguese language, literature, foreign language, physical education, information technology and communication) - plus a written essay.

As a robustness check, we also look at the association of management with the school average in natural sciences and languages and codes as well as on the $9^{\text {th }}$ grade average score of Prova Brasil - a national exam established in 2005 assessing all pupils in public education with at least 20 pupils enrolled in the grade assessed. For pupil characteristics used as controls in the performance regressions, such as gender composition, percentage of pupils with a foreign background among others which were not collected during the survey, we use INEP's 2011 Census Escolar (School Census) publicly available database (www.inep.gov.br).

\section{Sweden}

We use the $9^{\text {th }}$ grade GPA and the percentage of pupils qualifying for upper secondary school as the two main performance measures in Sweden. Both of these measures (as well as school and pupil characteristics) are available online at the Skolverket website (www.skolverket.se, siris.skolverket.se) for the large majority of the schools in our dataset. The $9^{\text {th }}$ grade GPA measure consists of the sum of points for the 16 best subjects in the pupil's final grade. For each subject, pupils can pass, pass with merit, or pass with distinction. For a pass they receive 10 points, for merit pass 15 points, and for distinction 20 points. The $9^{\text {th }}$ grade GPA is calculated for those pupils who received grades in at least one subject. The percentage of pupils qualifying for upper secondary school measure consists of the percentage of pupils who are eligible to apply to upper secondary school national programs. To be eligible, a pupil needs to receive a minimum pass in three core subjects in Swedish compulsory education: Swedish or Swedish as a second language, English, and math.

\section{United Kingdom}

As our main performance indicator in the UK, we use the average uncapped GCSE score which is publicly available in the Key Stage 4 performance tables at the National Archives at the Department of Education website (www.gov.uk/dfe).

The proportion of pupils achieving 5 GCSEs A-C* (Level 2 threshold), and more recently, the contextual value added measure have been the main indicators used to assess secondary school performance in the UK. However, we choose to use the average uncapped GSCE score because the average uncapped GSCE score provides a fuller picture of the achievements of pupils of all abilities. Nonetheless, we show the effect of management on the contextual value added measure in our main table and on proportion of pupils achieving 5 GCSEs A-C* (Level 2 threshold) in Table B3. 
For pupil characteristics not collected during the survey and used as controls in the performance regressions such as pupil gender composition, pupil ethnicity, pupil receiving free school meals among others, we use UK LEA and School Information Service (LEASIS) 2009 database.

\section{Countries with a non-standardized examination system}

\section{Canada}

Due to the lack of a comparable pupil examination scores across provinces in Canada, we use a rating indicator produced by the Fraser Institute (www.fraserinstitute.org), a Canadian think-tank that publishes school reports for all schools (independent, separate and public) in the provinces of Alberta, British Columbia, and Ontario.

This measure consists of an overall relative rating out of 10 , based on standardized scores, which ranks all secondary schools within provinces. That is, in order for a school to show improvement in its overall rating out of 10, it must improve more rapidly than the average. If it improves at a rate less than the average, it will show a decline in its rating. The rating for each province takes a combination of several indicators of pupil achievement into account, including exam marks, percentage of exams failed or below standard, courses taken per pupil, gender gaps, graduation rates and delayed advancement rates. The rating for each province is built as follows:

- Schools in Alberta: the overall rating out of 10 takes into account the average exam mark, the percentage of exams failed, school vs. exam mark difference, gender gaps, no of courses taken per pupil, diploma completion rate and delayed advancement rate.

- Schools in British Columbia: the overall rating out of 10 takes into account the average exam mark, percentage of failed exams, school versus exam mark difference, gender gaps, graduation rate and delayed advancement rate.

- Schools in Ontario: the overall rating out of 10 takes into account the average level Grade 9 math, percentage of pupil passing the OSSLT, percentage of tests below standard, and gender gap.

The school reports provided by the Fraser Institute also contain the pupil characteristics data used in the performance regressions.

\section{India}

For Indian schools, we use the average math scores in the X Standard examinations as our main indicator and the average science, and average first language scores in the same examination for robustness checks. After the completion of the tenth grade, pupil in India are required to sit for national board exams or state board exams, depending on which central institution the school is affiliated to. These examinations consist of multiple choice and short and long essay questions in the fields of math, physical sciences, social sciences, and languages among others and are based on each board's syllabus for Class X. The percentage scored in this examination determines not only the pupil's eligibility for graduation but also which field of study such as Science, Business or Arts the pupil can enrol in class XI. Although the X Standards examinations are mandatory for all schools under government school boards, the Central Board of Secondary Education (a Pan-Indian Private School Board) has made this examination optional to its pupil and allowed schools to accept their internal exam scores for graduation since 2010. We verify whether the quality of this examination is comparable across regions by searching for the examination format and subjects in math across a selected number of boards, as shown in Table A4.

The results of the X Standard examinations are not publicly available. Instead, we collected these results one month after the end of the survey by calling the person in charge of administering the $X$ Standard examinations in each school and asking for the average score, the overall number of points possible, the number of pupil sitting in the examination, and the number of pupil passing the examinations for each compulsory subject in the examination (usually math, sciences, first language, second language). We used the same procedure to collect the pupil characteristics used in the performance regressions, cross-checking this information with the information available in the DISE database (www.dise.in).

\section{United States}

We construct measures of school performance using the math exam pass rate from High School Exit Exams (HSEEs) and End-of-Course Exams (EOCs). For robustness checks we use the science and reading exam pass rates. The states where performance measures were available are the following: Alabama, Arizona, Arkansas (math and science only), California (math only), Colorado, Florida (math and reading only), Georgia (math and science only), Illinois, Louisiana (math and science only), Massachusetts (math and science only), Minnesota (math and reading only), New Jersey (math only), New York (math and science only), North Carolina (math and 
science only), Ohio, Oklahoma (math and reading only), Oregon, Pennsylvania, Texas (math and science only), Virginia (math and science only), Washington, Wisconsin, and Wyoming. These measures were compiled using publicly available data found in the department of education websites of each state.

This constructed measure of school performance gives rise to the question of whether it is a comparable measure to use in our analysis. Indeed, some states use HSSEs (examinations on 9th or 10th grade subjects taken by 11th or 12th grade pupil) where the subjects are usually grouped together as math, read, science, and social studies. Other states use mandatory EOC examinations to withhold pupil diplomas where pupil are tested on several topics within these main subjects such as Algebra, Geometry, Physics, Biology, and Chemistry (for example, Arkansas, New York, North Carolina, and Virginia have passing scores for separate math-related subjects so there is no overall passing percentage for just math). Furthermore, some of the states administering EOC examinations have not started withholding diplomas yet, thus, these examinations are not mandatory. ${ }^{1}$ In Table A5, we check for the comparability of HSSEs and EOCs across states by examining the format and tested subjects in math for all state containing performance measures in our dataset. ${ }^{2}$

For pupil characteristics used as controls in the performance regressions, such as gender composition, pupil ethnicity among others which were not collected during the survey, we use the publicly available NCES CCD Public School Survey Data 2008-2009 (https://nces.ed.gov/ccd/).

\section{APPENDIX B: ADDITIONAL RESULTS}

Tables B1 and B2 contain descriptive statistics from our sample. Table B3 has the robustness tests of the pupil performance regressions using alternative measures of school-level pupil outcomes. Table B4 has the robustness tests of the pupil performance regressions decomposing the management index. Table B5 disaggregates the management regressions in Table 3 by OECD country. Table B6 presents the specifications of Table 4 in Brazil and India.

\section{APPENDIX C: SAMPLING FRAME}

\section{C1. The Sampling Frame and Eligibility to Participate in the Survey}

In every country the sampling frame for the management survey included all schools offering education to 15 year-olds (excluding special needs schools) with 50 or more pupils in total. ${ }^{3}$ In order to ensure comparability across countries, we refrained from saying only "secondary or high schools" because some schools educate children from kindergarten to the end of high school (and we did not want to exclude them from the sample). The source of this sampling frame by country is shown in Table $\mathrm{C} 1$.

Interviewers were each given a randomly selected list of schools from the sampling frame. This should therefore be representative of the population of schools in the country. At schools, we either interviewed the principal, headteacher or school director, that is, the school leader at the top of the organization who is still involved in its management on a daily basis. The school leaders also had to be in the post for at least one year at the time of the interview.

\footnotetext{
${ }^{1}$ The main controversy surrounding HSEEs is twofold: 1) pupils who think they might fail the test might not take it in the first place and instead drop out of high school and, 2) local school authorities, principals and teachers have an extra incentive if pupils do well so the passing/proficient percentage might be higher but so are the dropout rates. For more information on this topic, see Warren, Jenkins, and Kulick (2006).

2 This table is an updated version of the table available on the following website: http://sites.google.com/site/highschoolexits/home/examsbystate

${ }^{3}$ The exception to this is India. Due to the lack of readily available sampling frames for secondary education in India, we constructed a sampling frame which only included schools that offered education at both the primary and secondary level, that is, the grades/level offered by the school included primary as well as secondary education (list of schools available at the District Information System for Education website). We were able to complement this sampling frame with the database of the two pan-Indian school networks, the Central Board for Secondary Education and the Indian Council of Secondary Education, which comprised of all secondary member schools, including schools only offering secondary education.
} 
Table C2 shows the number of schools in the sampling frame. The median schools in the UK, Italy (information available for public schools only), and Germany are larger as measured by the number of pupil in the schools while the median schools in Brazil and India are the smallest. In terms of the percentage of schools which are funded and managed exclusively by government authorities (this excludes escolas de referência in Brazil, separate schools in Canada, private ersatzschulen in Germany, private aided schools in India, friskolor in Sweden, academies, foundation schools and voluntary aided schools in the UK, and charter and magnet schools in the US), the UK has the smallest share (46\%) while Sweden has the largest share $(88 \%)$.

\section{C2. The Survey Response Rates}

Table C3 shows the survey response rates by country. The first column of each country represents all schools in the randomly selected list of schools given to the interviewers as described above. The second column represents all schools eligible for the interview. The eligibility criteria were confirmed by the interviewer during the process of contacting and scheduling the interview. In terms of interviews completed, we managed to obtain a response rate ranging from $58 \%$ and $42 \%$ of eligible schools in Brazil and India, respectively, to $8 \%$ of eligible schools in the UK. In contrast, the explicit refusal rate was generally low across all countries surveyed, ranging from $2 \%$ of all eligible schools in Sweden to $16 \%$ of all eligible schools in Germany.

The high response rate in Brazil and India was due to greater persistence in following up non-respondents in order to meet the target numbers we were aiming for and to the fact that most principals interviewed in these countries responded with a scheduled time and date soon after the first or second contact with the interviewer. As for the UK, there are a number of possible reasons for why the response rate was lower, including the proliferation of cold-calling and the increasing number of telephone surveys in schools in the UK (which makes running telephone surveys harder as switchboards more aggressively screen out calls), the domestic bias (phoning UK schools from the UK representing a study from a UK University is less impressive than, for example, phoning Brazilian schools from the UK), and principals' slow turnaround time for a response after the initial contact by interviewers (which was common throughout the North American and European countries surveyed).

"Scheduling in progress" indicates schools which have been contacted by an interviewer and which have not refused to be interviewed (for example they may schedule an interview but cancel or postpone it or simply take more time to respond). The high share of "scheduling in progress" schools was due to the need for interviewers to keep a stock of between 100 to 300 schools to cycle though when trying to arrange interviews. Since interviewers only ran an average of 1.4 interviews a day the majority of their time was spent trying to contact principals to schedule future interviews. The optimal level of this stock varied by the country: many US and Canadian managers operated voicemail, so that large stocks of firms were needed, while UK managers typically had personnel assistants rather than voicemail, who wanted to see Government endorsement materials before connecting with the managers. In addition, in the North American and European countries, a portion of the survey wave took place when principals were on holiday during the summer months. Unfortunately, the survey ended before these principals could be interviewed, which left large stocks of initially contacted schools without possibility of following up but were still considered under the "scheduling in progress" category.

The ratio of successful interviews to rejections (ignoring "scheduling in progress") is above 1 in every country, except in the UK. Hence, managers typically agreed to the survey proposition when interviewers were able to connect with them. This agreement ratio is lowest in the UK for the same reasons the response rate was lower: proliferation of phone surveys, domestic bias, personal assistants acting as tough gatekeepers, and slow turnaround time for a response after initial contact.

Finally, after initial contact, many schools were deemed not eligible for an interview, that is, the information in the sampling frame wrongly reported these schools as offering general education to 15 -year-olds or enrolling more than 50 pupils in the sampling frames, or interviewer verified that the principal had been in the post for less than one year. One of the reasons for a lower average of school interviews conducted per day in comparison to the average for our manufacturing interviews ( 2.8 per day) is the fact that analysts spent a significant time on the phone screening out non-eligible schools. 


\section{C3. Selection Analysis}

Panel A of Table $\mathrm{C} 4$ analyses the probability of being interviewed. ${ }^{4}$ Within each country, we compare the responding schools with those eligible schools in the sampling frame - including "interviews refused" and "scheduling in progress" but removing "schools not eligible" for the survey - against three types of selection bias: size (number of pupils), ownership (share of regular government schools) and population density (number of habitants per square kilometer) by state, province, or NUTS 2 region as a measure of location.

Looking at the overall pattern of results, there are very few significant coefficients and the marginal effects are small in magnitude. First, there is a tendency for larger schools to be more likely to respond, although this is only significant in Canada. The US is unusual in that smaller schools are significantly more likely to be interviewed. ${ }^{5}$ Second, government schools were no more likely to respond, except in India. Third, schools in densely populated areas tended to be less likely to respond, although this only significant at the $5 \%$ level in India ${ }^{6}$ and only at the $10 \%$ level in the US and Brazil.

To address selection concerns, we used the regressions in Table C4 to construct sampling weights. We then plot our cross-country ranking using the estimated weights. We found that the rankings across countries for the unweighted scores in Figure 1 were very robust when using these alternative sample weighting schemes. For example, Figure $\mathrm{C} 1$ below gives the equivalent of Figure 1 using the weights from Panel A of Table C4.

Panel B of Table $\mathrm{C} 4$ analyses the probability of being interviewed and of having pupil outcome measures publicly available. Within each country, we compare these schools with eligible school in the rest of the sampling frame, including schools for which we have a management interview against the same three types of selection bias as specified in Panel A. First, the results indicate that larger schools are more likely to have pupil outcomes data available in Canada (where performance data is only available in three major provinces) and the UK and (albeit we have performance data for 86 of the 92 schools interviewed) while smaller schools in India are more likely to have pupil outcome data (where data was collected through a short school performance telephone survey). Nonetheless, the coefficient magnitudes are small. Second, regular government schools in Brazil and the US are more likely to have pupil outcomes data available, however the magnitude of the coefficient in Brazil is small (we have performance data for 472 of the 513 schools interviewed) while the larger coefficient in the US reflects the unavailability of data for non-regular government schools for the majority of states. Third, schools in densely populated areas are more likely to have pupil outcomes data available in Canada and the UK, while schools in less populated areas are more likely to have pupil outcomes data in India (although this is marginally significant in the UK and India).

\footnotetext{
${ }^{4}$ Note this sample is smaller than the total survey sample because we do not have enrolment or ownership data for all schools in our survey sample.

${ }^{5}$ The reason for this is that many US principals from smaller schools did not have assistants who could potentially block our calls. Instead, many principals display their direct lines on the schools websites, which made it easier for our interviewers to reach them.

${ }^{6}$ For our Indian random survey sample, private school phone numbers (from CBSE and ICSE databases) were available while no phone numbers were available for government schools (from the DISE database). For many schools, we were not able to find either phone numbers or any information online and, thus, we were not able to verify whether these schools were still functioning. The interviewers were instructed to categorize these schools as out-of-business/no phone number found (that is, not eligible for the survey), thus decreasing the share of government schools in the eligible school sample. As interviewers were instructed to persistently call government schools in order to balance the sample, we now see a higher marginal effect of being interviewed which is inflated due to the fact that we had a much lower share of government schools in the eligible sample.
} 
FIGURE B1: PEOPLE AND NON-PEOPLE MANAGEMENT WITHIN COUNTRIES
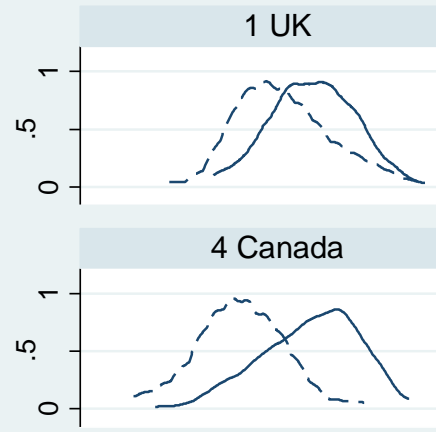

7 Brazil

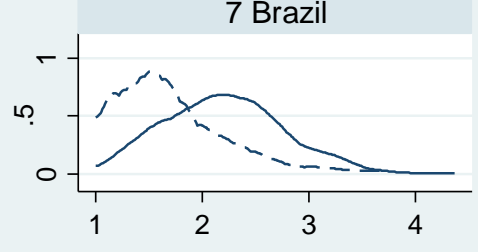

Graphs by Country

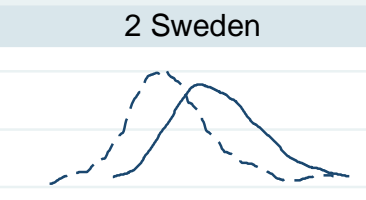

5 Germany

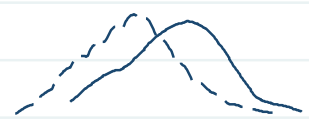

8 India

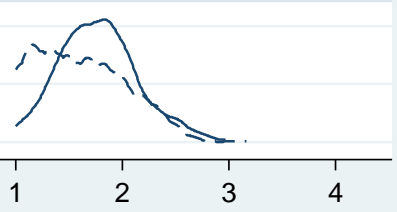

$\mathrm{X}$

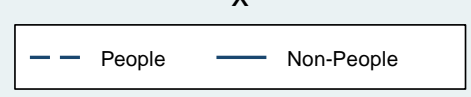

Notes: Data from 1,851 obs. (513 BR, 146 CA, 140 GE, 318 IN, 284 IT, 88 SW, 92 UK, 270 US schools).

FIGURE C1: CROSS COUNTRY AVERAGE MANAGEMENT SCORES CORRECTED FOR SAMPLING RESPONSE RATES

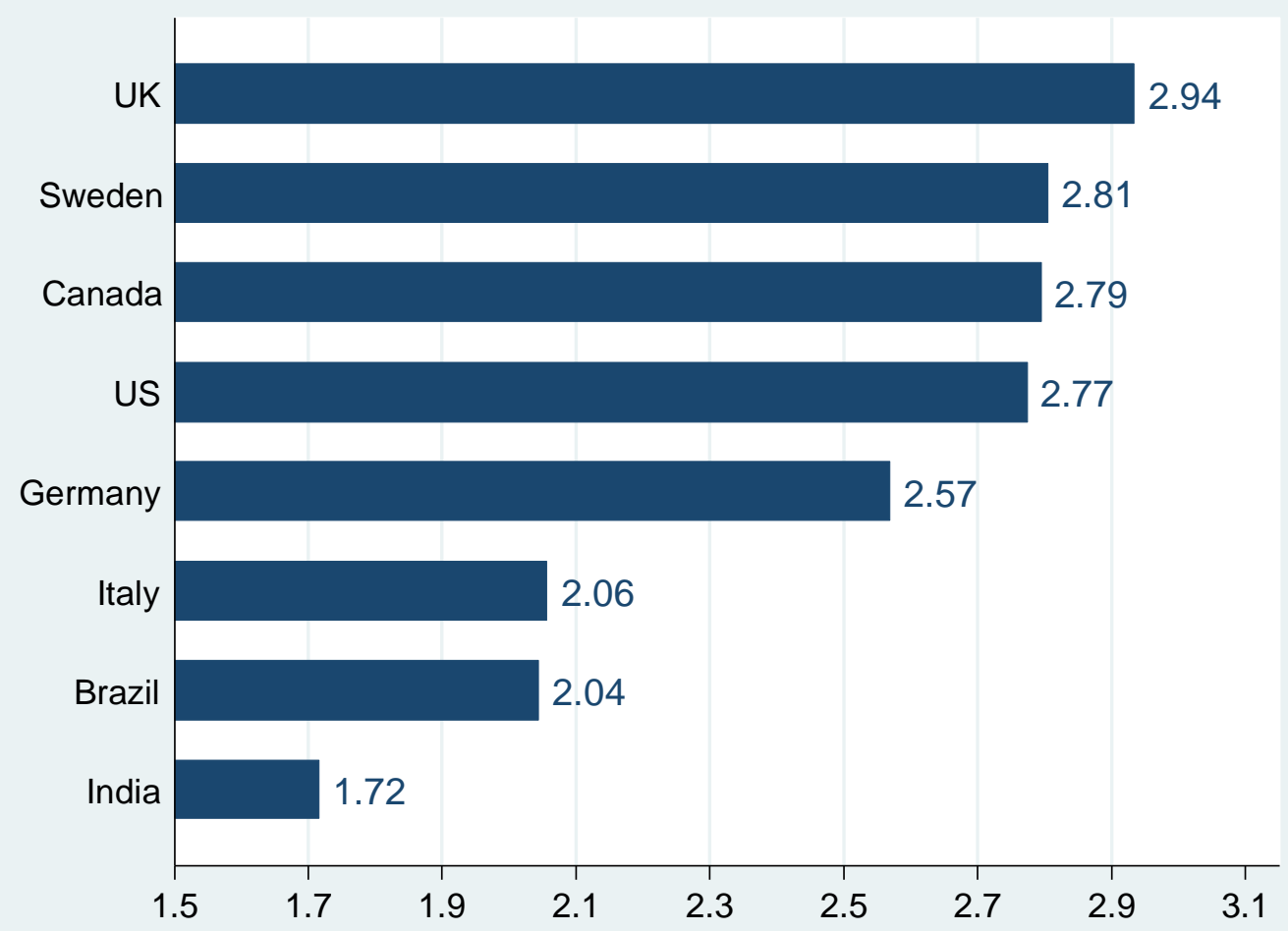

Notes: Average management score using sample weights constructed from the sample selection model in Table C4. Data from 1,851 obs. (513 BR, 146 CA, 140 GE, 318 IN, 284 IT, 88 SW, 92 UK, 270 US schools). 
TABLE A1: LIST OF MANAGEMENT PRACTICES

Operations:

Q1. Standardization of Instructional Planning Processes

Q2. Personalization of Instruction and Learning

Q3. Data-Driven Planning and Pupil Transitions

Q4. Adopting Educational Best Practices
Measures how well materials and practices are standardized and aligned in order to be capable of moving pupils through learning pathways over time

Measures for flexibility in teaching methods and pupil involvement ensuring all individuals can master the learning objectives

Measures if the school uses assessment to verify learning outcomes at critical stages, make data easily available and adapt pupil strategies accordingly

Measures how well the school incorporates teaching best practices and the sharing of these resources into the classroom

Monitoring:

\begin{tabular}{|l|l|}
\hline $\begin{array}{l}\text { Q5. Continuous } \\
\text { Improvement }\end{array}$ & Measures attitudes towards process documentation and continuous improvement \\
\hline $\begin{array}{l}\text { Q6. Performance } \\
\text { Tracking }\end{array}$ & $\begin{array}{l}\text { Measures whether school performance is measured with the right methods and } \\
\text { frequency }\end{array}$ \\
\hline Q7. Performance Review & $\begin{array}{l}\text { Measures whether performance is reviewed with appropriate frequency and follow- } \\
\text { up }\end{array}$ \\
\hline Q8. Performance Dialogue & Measures the quality of review conversations \\
\hline $\begin{array}{l}\text { Q9. Consequence } \\
\text { Management }\end{array}$ & $\begin{array}{l}\text { Measures whether differing levels of school performance (not only individual teacher } \\
\text { performance) lead to different consequences }\end{array}$ \\
\hline
\end{tabular}

Target Setting:

\begin{tabular}{|l|l|}
\hline Q10. Target Balance & Measures whether the system tracks meaningful targets tied to pupil outcomes \\
\hline $\begin{array}{l}\text { Q11. Target } \\
\text { Interconnection }\end{array}$ & $\begin{array}{l}\text { Measures whether the school and individual targets are aligned with each other and } \\
\text { the overall system goals }\end{array}$ \\
\hline $\begin{array}{l}\text { Q12. Time Horizon of } \\
\text { Targets }\end{array}$ & $\begin{array}{l}\text { Measures whether the school has a rational approach to planning and setting the } \\
\text { targets }\end{array}$ \\
\hline Q13. Target Stretch & Measures whether targets are appropriately difficult to achieve \\
\hline $\begin{array}{l}\text { Q14. Clarity and } \\
\text { Comparability of Targets }\end{array}$ & $\begin{array}{l}\text { Measures how easily understandable performance measures are and whether } \\
\text { performance is openly communicated }\end{array}$ \\
\hline
\end{tabular}

People/Talent Management:

\begin{tabular}{|l|l|}
\hline $\begin{array}{l}\text { Q15. Rewarding High } \\
\text { Performers }\end{array}$ & Measures whether good teacher performance is rewarded proportionately \\
\hline $\begin{array}{l}\text { Q16. Fixing Poor } \\
\text { Performers }\end{array}$ & Measures whether the school is able to deal with underperformers \\
\hline $\begin{array}{l}\text { Q17. Promoting High } \\
\text { Performers }\end{array}$ & Measures whether promotions and career progression are based on performance \\
\hline $\begin{array}{l}\text { Q18. Managing Talent } \\
\text { Q19. Retaining Talent }\end{array}$ & $\begin{array}{l}\text { Measures how well the school identifies and targets needed teaching, leadership and } \\
\text { other capacity in the school }\end{array}$ \\
\hline $\begin{array}{l}\text { Q20. Creating a } \\
\text { Distinctive Employee } \\
\text { Value Proposition }\end{array}$ & Measures how strong the teacher value proposition is to work in the individual school \\
\hline
\end{tabular}

Notes: Detailed survey instrument available at www.worldmanagementsurvey.org 


\section{TABLE A2: PRINCIPAL LEADERSHIP \& ACCOUNTABILITY MEASURES}

\begin{tabular}{|l|l|}
\hline $\begin{array}{l}\text { Leadership Vision \& } \\
\text { Strategy }\end{array}$ & $\begin{array}{l}\text { Measures whether schools leaders have an understanding of the broader set of } \\
\text { challenges that the school, system and key actors face and the right mind-set to } \\
\text { address them by checking whether the vision is clearly defined, set with the } \\
\text { collaboration of a wide range of stakeholders, broadly communicated, linked to pupil } \\
\text { outcomes and built upon a keen understanding of community needs. }\end{array}$ \\
\hline $\begin{array}{l}\text { Clearly Defined } \\
\text { Accountability for School } \\
\text { Leaders }\end{array}$ & $\begin{array}{l}\text { Measures whether school leaders are accountable for delivery of targets (including } \\
\text { quality, equity, and cost-effectiveness of pupil outcomes), are held responsible with } \\
\text { both school and individual-level consequences for good and bad performance, and } \\
\text { are autonomous in order to make decision that will directly affect the outcomes of } \\
\text { these targets. }\end{array}$ \\
\hline
\end{tabular}

Notes: All questions are scored on a 1 to 5 scale with $1=$ lowest scores and $5=$ highest score. Detailed survey instrument available at www.worldmanagementsurvey.org.

\section{TABLE A3: PRINCIPAL AUTONOMY MEASURES}

\begin{tabular}{|l|l|}
\hline Personnel Autonomy & To hire a full-time teacher what agreement would you need? \\
\hline Budgetary Autonomy & $\begin{array}{l}\text { What is the largest capital investment you can make without prior authorization from } \\
\text { outside? }\end{array}$ \\
\hline $\begin{array}{l}\text { Academic Content } \\
\text { Autonomy }\end{array}$ & $\begin{array}{l}\text { To add a new class - for example, introducing a new language such as Mandarin - } \\
\text { what agreement would you need? }\end{array}$ \\
\hline
\end{tabular}

Notes: To measure the degree of autonomy we use a 1-5 scale where 1 refers to no authority to make any decision and 5 refers to complete authority to make any decision. Detailed survey instrument available at www.worldmanagementsurvey.org 
TABLE A4: INDIA X STANDARD EXAMS (CLASS 10)

\begin{tabular}{|c|c|c|c|c|c|}
\hline State & Test Name & $\begin{array}{l}\text { Cove } \\
\text { rage }\end{array}$ & $\begin{array}{c}\text { Man } \\
\text { dator } \\
\text { y? }\end{array}$ & $\begin{array}{l}\text { Test Format for } \\
\text { Mathematics }\end{array}$ & Test Subjects for Mathematics \\
\hline AP & $\begin{array}{l}\text { Andhra Pradesh Board of } \\
\text { Intermediate Education }\end{array}$ & 10 & Yes & $\begin{array}{l}\text { Short Answer and Constructed } \\
\text { Response }\end{array}$ & Algebra, Vector Algebra, Trigonometry, Calculus, Coordinate Geometry \\
\hline GJ & $\begin{array}{l}\text { Gujarat Board of Secondary } \\
\text { Education }\end{array}$ & 10 & Yes & $\begin{array}{l}\text { Multiple Choice, Short } \\
\text { Answer, Very Short Answer } \\
\text { and Constructed Response }\end{array}$ & $\begin{array}{l}\text { Number system, Algebra (Polynomials, Rational Expressions, Linear } \\
\text { Equation, Quadratic Equations), Arithmetic Progression, Accounting } \\
\text { (Instalments, Income Tax), Mensuration, Trigonometry, Coordinate } \\
\text { Geometry. }\end{array}$ \\
\hline HR & Haryana Board of Education & 10 & Yes & $\begin{array}{l}\text { Multiple Choice, Short } \\
\text { Answer, Very Short Answer } \\
\text { and Constructed Response }\end{array}$ & $\begin{array}{l}\text { Number system (Real Numbers), Algebra (Polynomials, Linear Equation, } \\
\text { Quadratic Equations), Arithmetic Progression, Trigonometry (Triangles), } \\
\text { Coordinate Geometry }\end{array}$ \\
\hline $\mathrm{J} \& \mathrm{~K}$ & $\begin{array}{l}\text { J \& K State Board of School } \\
\text { Education }\end{array}$ & 10 & Yes & $\begin{array}{l}\text { Multiple Choice and } \\
\text { Constructed Response }\end{array}$ & $\begin{array}{l}\text { Algebra, Probability, Mensuration, Trigonometry, Coordinate Geometry, } \\
\text { Accounting (Instalments, Interest Rates) }\end{array}$ \\
\hline KA & $\begin{array}{l}\text { Secondary School Leaving } \\
\text { Certificate }\end{array}$ & 10 & Yes & $\begin{array}{l}\text { Multiple Choice, Very Short } \\
\text { Answer, Constructed } \\
\text { Response }\end{array}$ & Algebra, Mensuration, Coordinate Geometry \\
\hline $\mathrm{MH}$ & $\begin{array}{l}\text { The Maharashtra State } \\
\text { Secondary School Certificate }\end{array}$ & 10 & Yes & & $\begin{array}{l}\text { Number system, Algebra, Geometry, Trigonometry, Mensuration, Statistics, } \\
\text { Graphs and Coordinate Geometry }\end{array}$ \\
\hline CBSE & $\begin{array}{l}\text { All India Secondary School } \\
\text { Examination }\end{array}$ & 10 & No & $\begin{array}{l}\text { Multiple Choice, Short } \\
\text { Answer, Very Short Answer } \\
\text { and Constructed Response }\end{array}$ & $\begin{array}{l}\text { Algebra, Geometry, Mensuration, Trigonometry, Coordinate Geometry, } \\
\text { Probability }\end{array}$ \\
\hline ISCE & $\begin{array}{l}\text { Indian School Certificate } \\
\text { Examination }\end{array}$ & 10 & Yes & $\begin{array}{l}\text { Short Answer, Very Short } \\
\text { Answer, Constructed } \\
\text { Response. }\end{array}$ & $\begin{array}{l}\text { Number system, Algebra, Mensuration, Coordinate Geometry, Accounting } \\
\text { (Interest Rates), Trigonometry, Probability. }\end{array}$ \\
\hline
\end{tabular}


TABLE A5: UNITED STATES HIGH SCHOOL EXIT EXAMS (HSEEs) AND END OF COURSE EXAMS (EOCs)

\begin{tabular}{|c|c|c|c|c|c|}
\hline State & Test Name & Coverage & $\begin{array}{c}\text { Man } \\
\text { dator } \\
\text { y? }\end{array}$ & $\begin{array}{l}\text { Test Format for } \\
\text { Mathematics }\end{array}$ & Test Subjects for Mathematics \\
\hline $\mathrm{AL}$ & $\begin{array}{l}\text { Alabama High School } \\
\text { Graduation Exam (AHSGE) }\end{array}$ & 11,12 & Yes & Multiple choice & Algebra and Pre-Geometry \\
\hline $\mathrm{AZ}$ & $\begin{array}{l}\text { Arizona's Instrument to Measure } \\
\text { Standards (AIMS) }\end{array}$ & $\begin{array}{l}9,10,11 \\
12\end{array}$ & Yes & Multiple choice & Algebra I \& II and Geometry \\
\hline AR & End Of Course Exams (EOC) & HS & Yes & $\begin{array}{l}\text { Multiple Choice and } \\
\text { Constructed Response }\end{array}$ & $\begin{array}{l}\text { Statistics, Data Analysis, Probability, Measurement and Geometry, Number } \\
\text { Sense, Mathematical Reasoning, Algebra }\end{array}$ \\
\hline $\mathrm{CA}$ & $\begin{array}{l}\text { California High School Exit } \\
\text { Examination (CAHSEE) }\end{array}$ & $10,11,12$ & Yes & Multiple Choice & $\begin{array}{l}\text { Number Sense, Algebra, Probability, Geometry and Measurement, Problem } \\
\text { - Solving, }\end{array}$ \\
\hline FL & $\begin{array}{l}\text { Florida's Comprehensive } \\
\text { Assessment Test (FCAT) }\end{array}$ & 10 & Yes & $\begin{array}{l}\text { Multiple Choice, } \\
\text { Performance Tasks, } \\
\text { Gridded Response }\end{array}$ & $\begin{array}{l}\text { Number and Operations, Measurement, Geometry and Spatial Sense, } \\
\text { Patterns, Functions, and Algebra, Data Analysis, Probability and Statistics }\end{array}$ \\
\hline GA & $\begin{array}{l}\text { Georgia High School } \\
\text { Graduation Tests (GHSGT) }\end{array}$ & 11 & Yes & Multiple Choice & $\begin{array}{l}\text { Number and Computation, Geometry and Measurement, Algebra, Data } \\
\text { Analysis }\end{array}$ \\
\hline IL & $\begin{array}{l}\text { Prairie State Achievement } \\
\text { Examination (PSAE) }\end{array}$ & 11 & No & Multiple Choice & $\begin{array}{l}\text { Number Sense, Estimation and Measurement, Algebra and Analytical } \\
\text { Methods, Geometry, Data Analysis and Probability }\end{array}$ \\
\hline LA & Graduation Exit Exam (GEE) & $\begin{array}{l}10 \text { (Eng \& } \\
\text { math), } 11 \\
(\text { sci \& soc) }\end{array}$ & Yes & $\begin{array}{l}\text { Multiple Choice and } \\
\text { Constructed Response }\end{array}$ & $\begin{array}{l}\text { Number Sense, Concepts, and Applications; Spatial Sense and Geometry; } \\
\text { Data Analysis, Probability, Statistics, and Discrete Math; Patterns, } \\
\text { Functions, and Algebra }\end{array}$ \\
\hline MA & $\begin{array}{l}\text { Massachusetts Comprehensive } \\
\text { Assessment System (MCAS) }\end{array}$ & $\begin{array}{l}9 / 10(\mathrm{sci}) \\
10 \text { (ela \& } \\
\text { math) }\end{array}$ & Yes & $\begin{array}{l}\text { Multiple Choice, Short } \\
\text { Answer, Open Response }\end{array}$ & $\begin{array}{l}\text { Algebra, Functions, and Graphs; Geometry and Trigonometry; Data } \\
\text { Analysis and Probability; }\end{array}$ \\
\hline $\mathrm{MN}$ & $\begin{array}{l}\text { Graduation Required } \\
\text { Assessment for Diploma } \\
\text { (GRAD) }\end{array}$ & $\begin{array}{l}11 \text { math), } \\
10 \text { (read), } \\
9 \text { (write) }\end{array}$ & Yes & Multiple Choice & $\begin{array}{l}\text { Numbers and Operations; Geometry and Measurement; Data Analysis and } \\
\text { Probability; Algebra }\end{array}$ \\
\hline NJ & $\begin{array}{l}\text { High School Proficiency Exam } \\
\text { (HSPA) }\end{array}$ & 11 & Yes & $\begin{array}{l}\text { Multiple Choice and } \\
\text { Open Ended }\end{array}$ & Algebra I \\
\hline NM & $\begin{array}{l}\text { New Mexico High School } \\
\text { Standards Assessment } \\
\text { (NMHSSA) }\end{array}$ & 11 & No & $\begin{array}{l}\text { Multiple Choice and } \\
\text { Constructed Response }\end{array}$ & $\begin{array}{l}\text { Algebra I, Geometry and Measurement, Probability and Statistics, Math } \\
\text { Processes and Tools }\end{array}$ \\
\hline
\end{tabular}




\begin{tabular}{|c|c|c|c|c|c|}
\hline NY & $\begin{array}{l}\text { New York State Education } \\
\text { Department Regents } \\
\text { Examinations (NYSEDRE) }\end{array}$ & HS & Yes & $\begin{array}{l}\text { Multiple Choice and } \\
\text { Short Answer }\end{array}$ & $\begin{array}{l}\text { Numbers and Operations; Algebraic Reasoning; Geometric Reasoning and } \\
\text { Measurement; Data, Statistics, and Probability }\end{array}$ \\
\hline $\mathrm{NC}$ & $\begin{array}{l}\text { North Carolina End of Course } \\
\text { Exams (NC EOC) }\end{array}$ & HS & Yes & Multiple Choice & Algebra I, Geometry, Algebra II \\
\hline $\mathrm{OH}$ & Ohio Graduations Tests (OGT) & 10 & Yes & $\begin{array}{l}\text { Multiple Choice and } \\
\text { Constructed Response }\end{array}$ & $\begin{array}{l}\text { Mathematical Processes, Numerical Operations and Relationships, } \\
\text { Geometry, Measurement, Statistics and Probability, Algebraic Relationships }\end{array}$ \\
\hline OK & $\begin{array}{l}\text { Oklahoma Core Curriculum } \\
\text { Tests (OCCT-EOI) }\end{array}$ & $\begin{array}{l}9,10,11, \\
12\end{array}$ & Yes & Multiple Choice & $\begin{array}{l}\text { Number operations and concepts, Geometry, Measurement, Algebra, Data } \\
\text { Analysis and Probability }\end{array}$ \\
\hline OR & $\begin{array}{l}\text { Oregon Assessment of } \\
\text { Knowledge and Skills (OAKS) }\end{array}$ & 10 & No & Multiple Choice & Numeration, Measurement, Estimation, Functions, Geometry, Probability \\
\hline PA & $\begin{array}{l}\text { Pennsylvania System of School } \\
\text { Assessment (PSSA) }\end{array}$ & 11 & Yes & $\begin{array}{l}\text { Multiple Choice and } \\
\text { Open Ended }\end{array}$ & $\begin{array}{l}\text { Numbers and Operations, Algebraic Concepts, Geometry, Measurement and } \\
\text { Data, Data Analysis and Probability }\end{array}$ \\
\hline TX & $\begin{array}{l}\text { Texas Assessment of } \\
\text { Knowledge and Skills (TAKS) }\end{array}$ & 11 & Yes & $\begin{array}{l}\text { Multiple Choice and } \\
\text { Short Answer }\end{array}$ & Algebra 1 \\
\hline VA & $\begin{array}{l}\text { Standards of Learning Tests } \\
\text { (SOL) }\end{array}$ & EOC & Yes & Multiple Choice & $\begin{array}{l}\text { Number and Operations; Geometry and Measurement; Functions and } \\
\text { Algebra; Data, Statistics, and Probability }\end{array}$ \\
\hline WA & $\begin{array}{l}\text { Washington Assessment of } \\
\text { Student Learning (WASL) }\end{array}$ & 10 & Yes & $\begin{array}{l}\text { Multiple Choice, Short } \\
\text { Answer, and Constructed } \\
\text { Response }\end{array}$ & $\begin{array}{l}\text { Number and Operations, Geometry, Data Analysis, Statistics and } \\
\text { Probability; Measurement; Algebra, Functions, and Patterns }\end{array}$ \\
\hline WI & $\begin{array}{l}\text { Wisconsin Knowledge Concepts } \\
\text { Exams (WKCE) }\end{array}$ & 10 & No & Multiple Choice & $\begin{array}{l}\text { Number and Operations; Geometry and Measurement; Functions and } \\
\text { Algebra; Statistics and Probability }\end{array}$ \\
\hline WY & $\begin{array}{l}\text { Proficiency Assessments for } \\
\text { Wyoming Students (PAWS) }\end{array}$ & 11 & No & $\begin{array}{l}\text { Multiple Choice and } \\
\text { Constructed Response }\end{array}$ & $\begin{array}{l}\text { Number and Operations, Algebra, Geometry and Measurement, Statistics } \\
\text { and Probability }\end{array}$ \\
\hline
\end{tabular}

Notes: Information on HSEEs and EOCs for the year of the survey (2009). 


\begin{tabular}{|c|c|c|c|c|c|}
\hline Variable & Mean & $\begin{array}{c}\text { Standard } \\
\text { Dev. }\end{array}$ & Min. & Max. & Obs \\
\hline Average Management Score & 2.27 & 0.612 & 1.00 & 4.15 & 1851 \\
\hline Average People Score & 2.00 & 0.624 & 1.00 & 4.00 & 1851 \\
\hline Average Non-People Score & 2.39 & 0.658 & 1.00 & 4.37 & 1851 \\
\hline \multicolumn{6}{|l|}{ Performance Measures (for 1,002 schools) } \\
\hline Average Management Score & 2.27 & 0.649 & 1.00 & 4.15 & 1002 \\
\hline HSNE (ENEM) Average Math Score & 514.20 & 74.326 & 328.10 & 774.69 & 472 \\
\hline Rating & 5.92 & 2.013 & 0.00 & 10.00 & 77 \\
\hline X Standards Average Math Score & 69.23 & 8.289 & 50.00 & 90.00 & 152 \\
\hline 9th Grade GPA & 211.53 & 20.992 & 122.00 & 274.20 & 83 \\
\hline HSEE Math Pass Rate & 69.96 & 23.119 & 0.00 & 100.00 & 133 \\
\hline Average Uncapped GCSE Score & 442.78 & 75.543 & 299.80 & 645.80 & 86 \\
\hline Contextual Value Added & 1002.81 & 17.258 & 957.60 & 1044.50 & 78 \\
\hline \multicolumn{6}{|l|}{ Ownership and Governance } \\
\hline Share of Private Schools & 0.27 & 0.443 & 0.00 & 1.00 & 1851 \\
\hline Share of Autonomous Government Schools & 0.06 & 0.244 & 0.00 & 1.00 & 1851 \\
\hline Share of Regular Government Schools & 0.67 & 0.471 & 0.00 & 1.00 & 1851 \\
\hline \multicolumn{6}{|l|}{ Leadership } \\
\hline Principal Strategy & 2.62 & 0.850 & 1.00 & 5.00 & 1851 \\
\hline Principal Accountability & 2.22 & 0.843 & 1.00 & 5.00 & 1851 \\
\hline \multicolumn{6}{|l|}{ Autonomy } \\
\hline Personnel Autonomy & 2.76 & 1.665 & 1.00 & 5.00 & 1851 \\
\hline Academic Content Autonomy & 2.89 & 1.473 & 1.00 & 5.00 & 1847 \\
\hline Capital (Budgetary) Autonomy & 5966.75 & 16551.250 & 0.00 & 178019.10 & 1732 \\
\hline \multicolumn{6}{|l|}{ School Characteristics } \\
\hline Number of Pupils & 6.35 & 0.874 & 2.30 & 8.58 & 1851 \\
\hline $\begin{array}{l}\text { Pupil/Teacher Ratio } \\
\text { Share of Schools with a Regular Curriculum (as } \\
\text { opposed to Vocational) } \\
\text { Share of Schools with Pupil Selection based on }\end{array}$ & 2.64 & 0.264 & 0.01 & 5.24 & 1851 \\
\hline Academics & 0.24 & 0.426 & 0.00 & 1.00 & 1408 \\
\hline \multicolumn{6}{|l|}{ Principal Characteristics } \\
\hline Number of Years in Post (Tenure) & 6.56 & 6.224 & 1.00 & 52.00 & 1850 \\
\hline $\begin{array}{l}\text { Share of Male Principals } \\
\text { Share of Principals with a }\end{array}$ & 0.56 & 0.496 & 0.00 & 1.00 & 1851 \\
\hline Science/Tech./Eng./Maths/Business Degree & 0.32 & 0.468 & 0.00 & 1.00 & 1690 \\
\hline \multicolumn{6}{|l|}{ Geographical Control } \\
\hline Population Density (number of people/Km2) & 704.75 & 2911.378 & 0.00 & 56348.08 & 1764 \\
\hline
\end{tabular}


TABLE B2: DIFFERENCES BETWEEN PRIVATE, AUTONOMOUS GOVERNMENT AND REGULAR GOVERNMENT SCHOOLS (IN DEVIATIONS

FROM COUNTRY MEANS)

\begin{tabular}{|c|c|c|c|c|c|c|c|c|c|}
\hline & \multicolumn{3}{|c|}{ Panel A: OECD } & \multicolumn{3}{|c|}{ Panel B: Brazil } & \multicolumn{3}{|c|}{ Panel C: India } \\
\hline & Private & $\begin{array}{c}\text { Autonomous } \\
\text { Gov. }\end{array}$ & $\begin{array}{c}\text { Regular } \\
\text { Gov. }\end{array}$ & Private & $\begin{array}{c}\text { Autonomous } \\
\text { Gov. }\end{array}$ & $\begin{array}{c}\text { Regular } \\
\text { Gov. }\end{array}$ & Private & $\begin{array}{l}\text { Autonomous } \\
\text { Gov. }\end{array}$ & $\begin{array}{c}\text { Regular } \\
\text { Gov. }\end{array}$ \\
\hline Management & 0.98 & 1.05 & 1.00 & 1.12 & 1.42 & 0.95 & 1.04 & 0.95 & 0.94 \\
\hline Pupils & 0.87 & 1.00 & 1.03 & 0.95 & 1.01 & 1.02 & 1.02 & 1.03 & 0.96 \\
\hline Pupils/teachers & 0.86 & 1.03 & 1.02 & 0.88 & 1.17 & 1.04 & 0.98 & 1.05 & 1.02 \\
\hline Regular curriculum & 1.02 & 1.02 & 0.99 & 1.04 & 1.05 & 0.99 & 1.00 & 1.00 & 1.00 \\
\hline Academic selection & 2.31 & 0.66 & 0.75 & 2.39 & 0.00 & 0.49 & 1.13 & 0.76 & 0.83 \\
\hline Population density in region & 1.17 & 1.07 & 0.96 & 1.33 & 0.13 & 0.89 & 1.01 & 1.04 & 0.98 \\
\hline Number of competitors & 1.14 & 1.00 & 0.97 & 1.22 & 0.77 & 0.92 & 1.02 & 1.02 & 0.96 \\
\hline Principal tenure (years) & 1.44 & 0.95 & 0.91 & 1.65 & 0.95 & 0.76 & 1.14 & 1.12 & 0.73 \\
\hline Principal gender (male) & 1.00 & 0.88 & 1.02 & 0.95 & 1.04 & 1.02 & 0.86 & 1.08 & 1.22 \\
\hline Principal has STEM background & 1.03 & 1.12 & 0.98 & 0.76 & 1.20 & 1.09 & 0.99 & 1.14 & 0.99 \\
\hline Principal personnel autonomy & 1.71 & 1.09 & 0.84 & 2.23 & 1.22 & 0.54 & 1.25 & 1.06 & 0.57 \\
\hline Principal budgetary autonomy & 1.05 & 0.99 & 0.99 & 1.89 & 2.72 & 0.71 & 1.08 & 0.88 & 0.90 \\
\hline Principal academic content autonomy & 1.17 & 1.05 & 0.96 & 1.97 & 1.52 & 0.64 & 1.19 & 1.06 & 0.67 \\
\hline Principal strategy & 0.92 & 1.06 & 1.01 & 1.05 & 1.21 & 0.98 & 1.04 & 0.81 & 0.96 \\
\hline Principal accountability & 1.02 & 1.03 & 0.99 & 1.29 & 1.48 & 0.89 & 1.08 & 0.84 & 0.90 \\
\hline Observations & 1,020 & 1,020 & 1,020 & 513 & 513 & 513 & 318 & 318 & 318 \\
\hline
\end{tabular}


TABLE B3: PUPIL OUTCOMES AND MANAGEMENT - ALTERNATIVE MEASURES

\begin{tabular}{|c|c|c|c|c|c|c|c|c|}
\hline Sample of countries: & $\begin{array}{c}\text { (1) } \\
\text { Brazil }\end{array}$ & $\begin{array}{c}(2) \\
\text { Brazil }\end{array}$ & $\begin{array}{c}\text { (3) } \\
\text { India }\end{array}$ & $\begin{array}{c}\text { (4) } \\
\text { India }\end{array}$ & $\begin{array}{c}\text { (5) } \\
\text { Sweden }\end{array}$ & $\begin{array}{l}\text { (6) } \\
\text { UK }\end{array}$ & $\begin{array}{l}\text { (7) } \\
\text { US }\end{array}$ & $\begin{array}{l}\text { (8) } \\
\text { US }\end{array}$ \\
\hline Dependent variable: & $\begin{array}{l}\text { Natural } \\
\text { Sciences } \\
\text { Average } \\
\text { (ENEM) }\end{array}$ & $\begin{array}{c}\text { Portuguese } \\
\text { \& Math } \\
\text { Average } \\
\text { (Prova } \\
\text { Brasil) }\end{array}$ & $\begin{array}{l}\text { Average } \\
\text { Science }\end{array}$ & $\begin{array}{c}\text { Average } \\
\text { First } \\
\text { Language }\end{array}$ & $\begin{array}{c}\% \\
\text { qualifying } \\
\text { for upper } \\
\text { sec. school }\end{array}$ & $\begin{array}{c}\% \\
\text { achieving } 5 \\
\text { GCSEs A- } \\
C^{*}\end{array}$ & $\begin{array}{c}\text { HSEE } \\
\text { Science } \\
\text { Pass }\end{array}$ & $\begin{array}{c}\text { HSEE } \\
\text { Reading } \\
\text { Pass }\end{array}$ \\
\hline Management (z-score) & $\begin{array}{c}0.120^{* *} \\
(0.055)\end{array}$ & $\begin{array}{l}0.190^{*} \\
(0.113)\end{array}$ & $\begin{array}{c}0.495 * * \\
(0.247)\end{array}$ & $\begin{array}{c}0.402 \\
(0.333)\end{array}$ & $\begin{array}{c}0.286 \\
(0.224)\end{array}$ & $\begin{array}{c}0.399 \\
(0.249)\end{array}$ & $\begin{array}{c}0.079 \\
(0.069)\end{array}$ & $\begin{array}{c}0.333^{* *} \\
(0.140)\end{array}$ \\
\hline Autonomous government school & $\begin{array}{c}0.064 \\
(0.361)\end{array}$ & $\begin{array}{c}0.007 \\
(0.390)\end{array}$ & $\begin{array}{l}0.412 * \\
(0.223)\end{array}$ & $\begin{array}{c}0.192 \\
(0.237)\end{array}$ & $\begin{array}{c}0.055 \\
(0.345)\end{array}$ & $\begin{array}{c}0.040 \\
(0.246)\end{array}$ & $\begin{array}{c}0.155 \\
(0.146)\end{array}$ & $\begin{array}{l}-0.182 \\
(0.349)\end{array}$ \\
\hline Private school & $\begin{array}{c}1.535 * * * \\
(0.105)\end{array}$ & & $\begin{array}{c}0.197 \\
(0.205)\end{array}$ & $\begin{array}{c}-0.299 \\
(0.313)\end{array}$ & & $\begin{array}{c}0.004 \\
(0.892)\end{array}$ & & \\
\hline Log(pupils) & $\begin{array}{c}0.186^{* * *} \\
(0.059)\end{array}$ & $\begin{array}{c}0.053 \\
(0.127)\end{array}$ & $\begin{array}{c}0.095 \\
(0.119)\end{array}$ & $\begin{array}{c}0.332 \\
(0.201)\end{array}$ & $\begin{array}{c}0.550 * \\
(0.286)\end{array}$ & $\begin{array}{l}-0.532 \\
(0.340)\end{array}$ & $\begin{array}{c}0.054 \\
(0.074)\end{array}$ & $\begin{array}{c}0.195 \\
(0.167)\end{array}$ \\
\hline Log(pupils/teachers) & $\begin{array}{c}-0.132 \\
(0.104)\end{array}$ & $\begin{array}{l}-0.038 \\
(0.222)\end{array}$ & $\begin{array}{l}-0.003 \\
(0.212)\end{array}$ & $\begin{array}{c}0.100 \\
(0.274)\end{array}$ & $\begin{array}{l}-0.057 \\
(0.287)\end{array}$ & $\begin{array}{c}0.741 \\
(0.765)\end{array}$ & $\begin{array}{l}-0.345 \\
(0.224)\end{array}$ & $\begin{array}{l}-0.652 \\
(0.658)\end{array}$ \\
\hline Pupils selected on academic merit & $\begin{array}{c}0.477 * * * \\
(0.155)\end{array}$ & $\begin{array}{c}-0.448 \\
(0.334)\end{array}$ & $\begin{array}{l}-0.042 \\
(0.172)\end{array}$ & $\begin{array}{l}-0.225 \\
(0.218)\end{array}$ & $\begin{array}{c}0.018 \\
(0.611)\end{array}$ & $\begin{array}{c}1.254 * * * \\
(0.322)\end{array}$ & $\begin{array}{c}0.096 \\
(0.242)\end{array}$ & $\begin{array}{c}-0.794 \\
(0.485)\end{array}$ \\
\hline General controls & Yes & Yes & Yes & Yes & Yes & Yes & Yes & Yes \\
\hline Pupil controls (country-specific) & Yes & Yes & Yes & Yes & Yes & Yes & Yes & Yes \\
\hline Observations & 472 & 263 & 152 & 152 & 82 & 86 & 105 & 72 \\
\hline
\end{tabular}

Notes: Significance at the $1 \%$ level denoted by $* * *$ and $* *$ for $5 \%$ and $* 10 \%$ level. OLS estimates with robust standard errors in parentheses under coefficients. We use the science and reading exam pass rates from HSEEs in US (government schools only), contextual value added and \% of pupils achieving 5 GCSEs A-C* (Level 2 threshold) in UK, \% of pupils qualifying for upper secondary school in Sweden, natural sciences in High School National Exam (ENEM) and Portuguese and math average in Prova Brasil in Brazil, X Standards Average science and first language score in India (Appendix A). Pupil achievement data Z-scored within country. Autonomous government schools are escolas de referência in Brazil, private-aided schools in India, friskolor in Sweden, academies, foundation, and voluntary-aided schools in the UK, and charter and magnet schools in the US. Management is z-score of the averaged of the z-scored 20 individual questions. General controls: regional dummies, school curriculum (academic vs. vocational) and noise (job post and tenure of interviewee; interviewer dummies, day of week; time of day and interview duration and reliability measure). Pupil controls: Brazil (\% of female pupils, \% of foreign and naturalized pupils, and \% of indigenous pupils), Canada (\% of pupils whose $1 \mathrm{st}$ language is known/believed to be other than English), India (\% of female pupils and \% of pupils who are native speakers of the local language), Sweden ( $\%$ of female pupils and \% of pupils whose 1 st language is Swedish in Sweden), UK ( $\%$ of female pupils, $\%$ of pupils whose 1 st language is not English, $\%$ of non-white pupils, and \% of pupils eligible for a school meal); and US (\% of female pupils, $\%$ of non-white pupils, and $\%$ of pupils eligible for a school meal). 
TABLE B4: PUPIL OUTCOMES AND MANAGEMENT - DECOMPOSITIONS OF MANAGEMENT PRACTICES

$\begin{array}{lllllll}\text { (1) } & \text { (2) } & \text { (3) } & \text { (4) } & \text { (5) } & \text { (6) } & \text { (7) }\end{array}$

\begin{tabular}{|c|c|c|c|c|c|c|c|}
\hline \multirow{2}{*}{$\begin{array}{l}\text { Dependent variable: } \\
\text { Management (z-score) }\end{array}$} & \multicolumn{7}{|c|}{ Cross-country pooled measure of pupil achievement (z-scored) } \\
\hline & $\begin{array}{c}0.232 * * * \\
(0.044)\end{array}$ & & & & & & \\
\hline Operations (z-scored) & & $\begin{array}{c}0.093 * * \\
(0.036)\end{array}$ & & & & & \\
\hline Monitoring (z-scored) & & & $\begin{array}{c}0.133 * * * \\
(0.036)\end{array}$ & & & & \\
\hline Targets (z-scored) & & & & $\begin{array}{c}0.158^{* * * *} \\
(0.038)\end{array}$ & & & \\
\hline People (z-scored) & & & & & $\begin{array}{c}0.257 * * * \\
(0.046)\end{array}$ & & \\
\hline $\begin{array}{l}\text { Comparable } \\
\text { Management (z-scored) }\end{array}$ & & & & & & $\begin{array}{l}0.248^{* * *} \\
(0.045)\end{array}$ & \\
\hline Dobbie-Fryer Index & & & & & & & $\begin{array}{c}0.134^{* * *} \\
(0.038)\end{array}$ \\
\hline $\begin{array}{l}\text { Autonomous government } \\
\text { school }\end{array}$ & $\begin{array}{c}0.396 * * * \\
(0.114)\end{array}$ & $\begin{array}{c}0.433 * * * \\
(0.117)\end{array}$ & $\begin{array}{c}0.428 * * * \\
(0.117)\end{array}$ & $\begin{array}{c}0.427 * * * \\
(0.115)\end{array}$ & $\begin{array}{c}0.365 * * * \\
(0.113)\end{array}$ & $\begin{array}{c}0.391 * * * \\
(0.114)\end{array}$ & $\begin{array}{c}0.426^{* * *} \\
(0.117)\end{array}$ \\
\hline Private school & $\begin{array}{c}1.139 * * * \\
(0.094)\end{array}$ & $\begin{array}{c}1.201 * * * \\
(0.095)\end{array}$ & $\begin{array}{c}1.205^{* * *} \\
(0.094)\end{array}$ & $\begin{array}{c}1.224^{* * *} \\
(0.095)\end{array}$ & $\begin{array}{c}1.015^{* * *} \\
(0.100)\end{array}$ & $\begin{array}{c}1.131^{* * *} \\
(0.094)\end{array}$ & $\begin{array}{c}1.175^{* * *} \\
(0.096)\end{array}$ \\
\hline Log(pupils) & $\begin{array}{l}0.075^{*} \\
(0.042)\end{array}$ & $\begin{array}{l}0.088^{* *} \\
(0.043)\end{array}$ & $\begin{array}{l}0.093 * * \\
(0.043)\end{array}$ & $\begin{array}{c}0.087 * * \\
(0.043)\end{array}$ & $\begin{array}{l}0.072^{*} \\
(0.042)\end{array}$ & $\begin{array}{l}0.077^{*} \\
(0.042)\end{array}$ & $\begin{array}{l}0.084 * * \\
(0.043)\end{array}$ \\
\hline Log(pupils/teachers) & $\begin{array}{l}-0.014 \\
(0.086)\end{array}$ & $\begin{array}{l}-0.023 \\
(0.087)\end{array}$ & $\begin{array}{l}-0.037 \\
(0.086)\end{array}$ & $\begin{array}{l}-0.022 \\
(0.087)\end{array}$ & $\begin{array}{l}-0.018 \\
(0.087)\end{array}$ & $\begin{array}{l}-0.019 \\
(0.086)\end{array}$ & $\begin{array}{l}-0.016 \\
(0.086)\end{array}$ \\
\hline $\begin{array}{l}\text { Pupils selected on } \\
\text { academic merit }\end{array}$ & $\begin{array}{c}0.477 * * * \\
(0.109)\end{array}$ & $\begin{array}{c}0.504^{* * *} \\
(0.111)\end{array}$ & $\begin{array}{c}0.512 * * * \\
(0.109)\end{array}$ & $\begin{array}{c}0.489^{* * *} \\
(0.110)\end{array}$ & $\begin{array}{c}0.453^{* * *} \\
(0.109)\end{array}$ & $\begin{array}{c}0.473^{* * *} \\
(0.109)\end{array}$ & $\begin{array}{c}0.503^{* * *} \\
(0.110)\end{array}$ \\
\hline Observations & 1,002 & 1,002 & 1,002 & 1,002 & 1,002 & 1,002 & 1,002 \\
\hline
\end{tabular}

Notes: Significance at the $1 \%$ level denoted by $* * *$ and $* *$ for $5 \%$ and $* 10 \%$ level. OLS estimates with robust standard errors in parentheses under coefficients. General controls and country dummies in all columns. We use the math exam pass rate from HSEEs in US (government schools only), uncapped GCSE score in UK, Fraser Institute school rating in Canada, 9th grade GPA in Sweden, average math score in High School National Exam (ENEM) in Brazil, average math score in X Standards in India (see Appendix A for details). Pupil achievement data z-scored within country. Autonomous government schools are escolas de referência in Brazil, separate schools in Canada, private ersatzschulen in Germany, private-aided schools in India, friskolor in Sweden, academies, foundation, and voluntary-aided schools in the UK, and charter and magnet schools in the US. The Management variable takes the average of all 20 management questions. The Non-People variable takes the average of all non-people practices, that is, all operations management, performance management, and target setting questions listed in Table A1 (Qs 1 to 14) in the Appendix. The People variable takes the average of all people related management questions in Table A1 (Qs 15 to 20) in the Appendix. The Comparable Management variable takes the average of 16 questions common to the school survey and surveys in other sectors in Table A1 in the Appendix (Qs 5 to 20, that is, all monitoring, target setting and people management questions). The DobbieFryer Index takes the average of 3 management questions: "Q3 - Data-driven Planning and Pupil Transitions", "Q4 - Adopting Education Best Practices", "Q2 - Personalization of Instruction and Learning", and 1 leadership question: "Clearly Defined Accountability for Principals". General controls are regional dummies, school curriculum (academic vs. vocational) and noise controls (job post and tenure of interviewee; up to 40 interviewer dummies, day of week; time of day interview conducted, interview duration and reliability measure). 


\begin{tabular}{|c|c|c|c|c|c|c|c|c|}
\hline $\begin{array}{l}\text { Sample of countries: } \\
\text { Dependent variable: }\end{array}$ & All & $\begin{array}{c}\text { (1) } \\
\text { Canada }\end{array}$ & $\begin{array}{c}\text { (2) } \\
\text { Germany }\end{array}$ & $\begin{array}{c}\text { (3) } \\
\text { Italy } \\
\text { Manage }\end{array}$ & $\begin{array}{c}\text { (4) } \\
\text { Sweden } \\
\text { (z-score) }\end{array}$ & $\begin{array}{l}\text { (5) } \\
\text { UK }\end{array}$ & $\begin{array}{l}\text { (6) } \\
\text { US }\end{array}$ & $\begin{array}{l}\text { (7) } \\
\text { All OECD } \\
\text { except } \\
\text { Sweden }\end{array}$ \\
\hline Autonomous government school & $\begin{array}{c}0.244 * * * \\
(0.075)\end{array}$ & $\begin{array}{c}0.030 \\
(0.100)\end{array}$ & $\begin{array}{c}0.237 \\
(0.204)\end{array}$ & & $\begin{array}{c}0.430 * * \\
(0.185)\end{array}$ & $\begin{array}{c}0.213 \\
(0.154)\end{array}$ & $\begin{array}{c}0.111 \\
(0.228)\end{array}$ & $\begin{array}{l}0.141^{*} \\
(0.077)\end{array}$ \\
\hline Private school & $\begin{array}{l}-0.004 \\
(0.076)\end{array}$ & $\begin{array}{c}0.176 \\
(0.189)\end{array}$ & $\begin{array}{c}0.790 \\
(0.498)\end{array}$ & $\begin{array}{c}0.007 \\
(0.144)\end{array}$ & & $\begin{array}{l}-0.055 \\
(0.448)\end{array}$ & $\begin{array}{l}-0.194 \\
(0.143)\end{array}$ & $\begin{array}{l}-0.009 \\
(0.079)\end{array}$ \\
\hline $\log$ (pupils) & $\begin{array}{c}0.113 * * * \\
(0.033)\end{array}$ & $\begin{array}{c}0.028 \\
(0.056)\end{array}$ & $\begin{array}{c}0.168 \\
(0.116)\end{array}$ & $\begin{array}{c}0.054 \\
(0.076)\end{array}$ & $\begin{array}{l}-0.057 \\
(0.139)\end{array}$ & $\begin{array}{c}0.678 * * * \\
(0.173)\end{array}$ & $\begin{array}{c}0.133 * * \\
(0.067)\end{array}$ & $\begin{array}{c}0.128 * * * \\
(0.035)\end{array}$ \\
\hline Log(pupils/teachers) & $\begin{array}{c}-0.150 * * \\
(0.070)\end{array}$ & $\begin{array}{c}0.123 \\
(0.142)\end{array}$ & $\begin{array}{c}-0.167 \\
(0.363)\end{array}$ & $\begin{array}{c}-0.134 \\
(0.123)\end{array}$ & $\begin{array}{c}-0.237 \\
(0.151)\end{array}$ & $\begin{array}{l}-0.545 \\
(0.615)\end{array}$ & $\begin{array}{l}-0.179 \\
(0.161)\end{array}$ & $\begin{array}{c}-0.152 * * \\
(0.075)\end{array}$ \\
\hline Pupils selected on academic merits & $\begin{array}{c}0.034 \\
(0.087)\end{array}$ & $\begin{array}{c}0.153 \\
(0.134)\end{array}$ & $\begin{array}{c}0.083 \\
(0.285)\end{array}$ & $\begin{array}{c}-0.032 \\
(0.184)\end{array}$ & $\begin{array}{c}0.338 \\
(0.309)\end{array}$ & $\begin{array}{c}0.037 \\
(0.240)\end{array}$ & $\begin{array}{c}0.084 \\
(0.272)\end{array}$ & $\begin{array}{c}0.060 \\
(0.088)\end{array}$ \\
\hline Regular (non-vocational) curriculum & $\begin{array}{c}0.165^{* *} \\
(0.074)\end{array}$ & & $\begin{array}{c}0.134 \\
(0.179)\end{array}$ & $\begin{array}{c}0.170 * * \\
(0.084)\end{array}$ & & & & $\begin{array}{c}0.164 * * \\
(0.074)\end{array}$ \\
\hline Log(population density) & $\begin{array}{c}0.057 * * * \\
(0.018)\end{array}$ & $\begin{array}{c}0.030 \\
(0.029)\end{array}$ & $\begin{array}{l}0.080^{*} \\
(0.048)\end{array}$ & $\begin{array}{c}-0.014 \\
(0.057)\end{array}$ & $\begin{array}{c}0.226^{*} \\
(0.132)\end{array}$ & $\begin{array}{l}-0.038 \\
(0.051)\end{array}$ & $\begin{array}{c}0.086^{* *} \\
(0.035)\end{array}$ & $\begin{array}{c}0.054 * * * \\
(0.018)\end{array}$ \\
\hline Regional dummies & No & Yes & Yes & Yes & Yes & Yes & Yes & Yes \\
\hline Noise controls & No & Yes & Yes & Yes & Yes & Yes & Yes & Yes \\
\hline Test Private $=$ Autonomous gov.: $p$-value & 0.028 & 0.438 & 0.303 & & & 0.503 & 0.192 & 0.128 \\
\hline Observations & 1,020 & 146 & 140 & 284 & 88 & 92 & 270 & 932 \\
\hline
\end{tabular}

Notes: Significance at the $1 \%$ level denoted by *** and ** for $5 \%$ and $* 10 \%$ level. OLS estimates with robust standard errors in parentheses under coefficients. Autonomous government schools are separate schools in Canada, private ersatzschulen in Germany, friskolor in Sweden, academies, foundation, and voluntary-aided schools in the UK, and charter and magnet schools in the US. Column (1) includes country dummies. Population density is at the NUTS3 level. Noise controls include up to 23 interviewer dummies, day of week; time of day interview conducted, interview duration, reliability measure, and job post of interviewee. 
TABLE B6: EXPLAINING THE ADVANTAGE OF AUTONOMOUS GOVERNMENT SCHOOLS: PRINCIPAL LEADERSHIP IN BRAZIL AND INDIA

(1)

Sample of countries:
(2)

Brazil
(3)

(4)

India

\begin{tabular}{|c|c|c|c|c|}
\hline Dependent variable: & $\begin{array}{l}\text { Management } \\
\text { (z-scored) }\end{array}$ & $\begin{array}{c}\text { Management } \\
\text { (z-scored) }\end{array}$ & $\begin{array}{l}\text { Management } \\
\text { (z-scored) }\end{array}$ & $\begin{array}{l}\text { Management } \\
\text { (z-scored) }\end{array}$ \\
\hline Autonomous government school & $\begin{array}{c}0.893^{* * *} \\
(0.181)\end{array}$ & $\begin{array}{c}0.436^{* *} \\
(0.198)\end{array}$ & $\begin{array}{c}0.002 \\
(0.110)\end{array}$ & $\begin{array}{c}0.055 \\
(0.095)\end{array}$ \\
\hline Private school & $\begin{array}{c}0.471 * * * \\
(0.082)\end{array}$ & $\begin{array}{l}-0.030 \\
(0.137)\end{array}$ & $\begin{array}{c}0.008 \\
(0.069)\end{array}$ & $\begin{array}{l}-0.076 \\
(0.061)\end{array}$ \\
\hline $\log ($ pupils) & $\begin{array}{l}0.125^{* *} \\
(0.058)\end{array}$ & $\begin{array}{c}0.078 \\
(0.048)\end{array}$ & $\begin{array}{c}0.221 * * * \\
(0.041)\end{array}$ & $\begin{array}{c}0.171 * * * \\
(0.036)\end{array}$ \\
\hline Log(pupils/teachers) & $\begin{array}{l}-0.079 \\
(0.103)\end{array}$ & $\begin{array}{l}-0.061 \\
(0.086)\end{array}$ & $\begin{array}{c}-0.288^{* * *} \\
(0.063)\end{array}$ & $\begin{array}{c}-0.134^{* *} \\
(0.053)\end{array}$ \\
\hline Competition & & $\begin{array}{l}-0.017 \\
(0.042)\end{array}$ & & $\begin{array}{c}0.054 \\
(0.046)\end{array}$ \\
\hline Principal tenure (years) & & $\begin{array}{c}-0.006^{* *} \\
(0.003)\end{array}$ & & $\begin{array}{l}-0.004 \\
(0.004)\end{array}$ \\
\hline Principal gender (male) & & $\begin{array}{l}-0.036 \\
(0.053)\end{array}$ & & $\begin{array}{l}-0.058 \\
(0.048)\end{array}$ \\
\hline Principal has STEM background & & $\begin{array}{c}0.054 \\
(0.056)\end{array}$ & & $\begin{array}{l}-0.011 \\
(0.045)\end{array}$ \\
\hline Principal personnel autonomy & & $\begin{array}{c}0.023 \\
(0.063)\end{array}$ & & $\begin{array}{l}-0.010 \\
(0.036)\end{array}$ \\
\hline Principal budgetary autonomy & & $\begin{array}{c}0.043 \\
(0.031)\end{array}$ & & $\begin{array}{c}0.015 \\
(0.034)\end{array}$ \\
\hline $\begin{array}{l}\text { Principal academic content } \\
\text { autonomy }\end{array}$ & & $\begin{array}{c}0.038 \\
(0.047)\end{array}$ & & $\begin{array}{c}0.018 \\
(0.029)\end{array}$ \\
\hline Principal accountability & & $\begin{array}{c}0.361 * * * \\
(0.033)\end{array}$ & & $\begin{array}{c}0.283 * * * \\
(0.040)\end{array}$ \\
\hline Principal strategy & & $\begin{array}{c}0.307 * * * \\
(0.031)\end{array}$ & & $\begin{array}{c}0.184^{* * *} \\
(0.038)\end{array}$ \\
\hline Regional dummies & Yes & Yes & Yes & Yes \\
\hline Noise controls & Yes & Yes & Yes & Yes \\
\hline Test Private $=$ Aut. gov.: p-value & 0.005 & 0.000 & 0.666 & 0.208 \\
\hline Observations & 513 & 513 & 318 & 318 \\
\hline
\end{tabular}

Notes: Significance at the $1 \%$ level denoted by $* * *$ and $* *$ for $5 \%$ and $* 10 \%$ level. OLS estimates with robust standard errors in parentheses under coefficients. The Management variable takes the average of all 20 management questions. Autonomous government schools are escolas de referência in Brazil and private-aided schools in India. Population density is at the NUTS3 level. Noise controls include 17 interviewer dummies, day of week; time of day interview conducted, interview duration, reliability measure, and job post of interviewee. The competition variable is collected during the survey itself by asking the principal "How many other schools offering education to 15 year-olds are within a 30-minute drive from your school?" STEM background refers to principals with a background in Science, Technology, Engineering, Maths, and Business. The autonomy questions were asked and measured during the survey. For personnel autonomy, we ask "To hire a full-time teacher what 
agreement would you need?, for budgetary autonomy, we ask "What is the largest capital investment you can make without prior authorization from outside?" and for academic content autonomy, we ask "To add a new class - for example, introducing a new language such as Mandarin - what agreement would you need?". To measure the degree of autonomy we use a 1-5 scale where 1 refers to no authority to make any decision and 5 refers to complete authority to make any decision. Principal accountability variable measures the degree to which the principal is responsible for delivering the school targets and the principal strategy variable measures the degree to which the principal communicates a well-established strategy for the school for the next 5 years. 
TABLE C1: SAMPLING FRAME SOURCES

\begin{tabular}{|l|l|}
\hline \hline Brazil & Instituto Nacional de Estudos e Pesquisas Educacionais (INEP) \\
\hline \multirow{3}{*}{ India } & Scott's Directories (Private company compiling information for all schools in Canada) \\
\hline Italy & District Information System for Education (DISE) \\
\cline { 2 - 2 } & Central Board for Secondary Education (CBSE) \\
\cline { 2 - 2 } & Indian Council of Secondary Education (ICSE) \\
\hline Sweden & Ministero dell'Istruzione, dell'Università e della Ricerca \\
\hline Germany & Skolverket (Swedish National Agency for Education) \\
\hline United States & Various state departments \\
\hline United Kingdom & National Center for Education Statistics \\
\hline \hline
\end{tabular}

TABLE C2: THE SAMPLING FRAME

\begin{tabular}{lcccccccc}
\hline \hline & BR & CA & DE & IN & IT & SE & UK & US \\
Number of schools (\#) & 28,390 & 4,122 & 7,184 & 49,856 & 4,954 & 4,142 & 4,243 & 24,301 \\
Pupils (median) & 258 & $\begin{array}{c}300- \\
499\end{array}$ & 579 & 218 & 745 & 209 & 845 & 407 \\
$\begin{array}{l}\text { Regular Government Schools } \\
(\%)\end{array}$ & 71.5 & & 77.1 & 65.1 & 66.5 & 87.8 & 45.9 & 65.4 \\
\hline \hline
\end{tabular}

Notes: $\mathrm{BR}=$ Brazil, $\mathrm{CA}=$ Canada, $\mathrm{DE}=$ Germany, $\mathrm{IN}=$ India, IT=Italy, $\mathrm{SE}=$ Sweden, UK=United Kingdom, US=United States. Sampling frame is the total number of schools eligible for the survey. The sampling frame includes all schools with 50 or more pupil offering education to 15 year-olds. Pupils is the median number of pupil in the school. When this information was not available, the school was kept in the sampling frame. The number of pupil is available for $97 \%$ of the sampling frame in Canada, $64 \%$ of the sampling frame in Germany (information available for BA, BR, BW, NRW, SH states only), for $85 \%$ of the sampling frame in India, $68 \%$ of the sampling frame in Italy (information available for government schools only), $95 \%$ of the sampling frame in Sweden. For all other countries - Brazil, UK and US - this information is available for $100 \%$ of the sampling frame. Regular Government Schools refers to the percentage of regular government schools which are funded \& managed exclusively by government authorities (this excludes private and autonomous government schools). This information is not available for Canadian schools. 
TABLE C3: THE SURVEY RESPONSE RATES

\begin{tabular}{|c|c|c|c|c|c|c|c|c|}
\hline & \multicolumn{2}{|c|}{ BR } & \multicolumn{2}{|c|}{$\mathbf{C A}$} & \multicolumn{2}{|c|}{ DE } & \multicolumn{2}{|c|}{ IN } \\
\hline & All & Eligible & All & Eligible & All & Eligible & All & Eligible \\
\hline Interviews completed $(\%)$ & 37.6 & 58.1 & 13.9 & 19.1 & 22.7 & 26.0 & 35.1 & 41.5 \\
\hline Interviews refused $(\%)$ & 8.2 & 12.7 & 4.5 & 6.1 & 14.3 & 16.3 & 7.6 & 9.0 \\
\hline Scheduling in progress $(\%)$ & 18.9 & 29.2 & 54.5 & 74.8 & 50.4 & 57.7 & 41.8 & 49.5 \\
\hline School not eligible (\%) & 35.4 & - & 27.1 & - & 12.7 & - & 15.6 & - \\
\hline Sample, numb. of firms (\#) & \multicolumn{2}{|c|}{1377} & \multicolumn{2}{|c|}{1073} & \multicolumn{2}{|c|}{631} & \multicolumn{2}{|c|}{907} \\
\hline \multirow[t]{3}{*}{ Interviews completed (\#) } & \multicolumn{2}{|c|}{517} & \multicolumn{2}{|c|}{149} & \multicolumn{2}{|c|}{143} & \multicolumn{2}{|c|}{318} \\
\hline & \multicolumn{2}{|c|}{ IT } & \multicolumn{2}{|c|}{ SE } & \multicolumn{2}{|c|}{ UK } & \multicolumn{2}{|c|}{ US } \\
\hline & All & Eligible & All & Eligible & All & Eligible & All & Eligible \\
\hline Interviews completed $(\%)$ & 45.2 & 56.6 & 29.8 & 35.6 & 7.3 & 7.9 & 17.2 & 20.1 \\
\hline Interviews refused $(\%)$ & 11.8 & 14.7 & 1.7 & 2.0 & 11.5 & 12.5 & 5.5 & 6.4 \\
\hline Scheduling in progress $(\%)$ & 22.9 & 28.7 & 52.2 & 62.4 & 73.6 & 79.6 & 63.0 & 73.5 \\
\hline School not eligible (\%) & 20.2 & & 16.3 & - & 7.6 & - & 14.3 & - \\
\hline Sample, numb. of firms (\#) & \multicolumn{2}{|c|}{773} & \multicolumn{2}{|c|}{295} & \multicolumn{2}{|c|}{1482} & \multicolumn{2}{|c|}{1618} \\
\hline Interviews completed (\#) & \multicolumn{2}{|c|}{349} & \multicolumn{2}{|c|}{88} & \multicolumn{2}{|c|}{108} & \multicolumn{2}{|c|}{279} \\
\hline
\end{tabular}

Notes: $\mathrm{BR}=$ Brazil, $\mathrm{CA}=$ Canada, $\mathrm{DE}=$ Germany, $\mathrm{IN}=$ India, IT=Italy, SE=Sweden, UK=United Kingdom, US=United States. 1) Interviews completed reports all the companies contacted for which a management interview was completed. These numbers might differ from the number of observations used in this paper because we drop any interviews which have a reliability score of less than 5 . We compute this measure by adding the scores (on a 1-5 scale) of two indicators provided by the interviewee after the interview is completed: i) the interviewee's knowledge of the management practices current in place at his or her school, and ii) the interviewee's willingness to reveal information about the management practices of his or her school. 2) Scheduling in progress reports all the companies contacted with no interview run or manager refusing to be interviewed. 3) Interviews refused reports all companies contacted in which the manager refused to take part in the interview. 4) No longer eligible reports all schools contacted which do not offer general education to 15 -year olds or have less than 50 pupils. It also included organizations out-of business or for which no phone number was found. Survey sample is the total number of firms that were randomly selected and contacted from the complete sampling frame. 


\begin{tabular}{|c|c|c|c|c|c|c|c|c|}
\hline Country: & BR & $\mathbf{C A}$ & DE & IN & IT & SE & UK & US \\
\hline Panel A & (1) & (2) & (3) & (4) & (5) & (6) & (7) & (8) \\
\hline Dependent variable: & \multicolumn{8}{|c|}{$=1$ if school interview occurred } \\
\hline \multirow[t]{2}{*}{ Log(pupils) } & 0.053 & $0.118 * *$ & 0.024 & 0.114 & -0.107 & 0.024 & 0.089 & $-0.085 * *$ \\
\hline & $(0.055)$ & $(0.056)$ & $(0.137)$ & $(0.073)$ & $(0.167)$ & $(0.166)$ & $(0.124)$ & $(0.043)$ \\
\hline \multirow[t]{2}{*}{$\begin{array}{l}\text { Regular Government } \\
\text { Schools }\end{array}$} & 0.151 & & 0.047 & $0.593 * * *$ & & 0.031 & -0.077 & 0.038 \\
\hline & $(0.106)$ & & $(0.171)$ & $(0.099)$ & & $(0.213)$ & $(0.110)$ & $(0.094)$ \\
\hline \multirow[t]{2}{*}{$\begin{array}{l}\text { Log(population density } \\
\text { in the region) }\end{array}$} & $-0.065^{*}$ & -0.091 & 0.059 & $-0.253 * * *$ & 0.046 & -0.050 & 0.065 & $-0.076^{*}$ \\
\hline & $(0.038)$ & $(0.059)$ & $(0.173)$ & $(0.060)$ & $(0.124)$ & $(0.070)$ & $(0.050)$ & $(0.039)$ \\
\hline
\end{tabular}

Panel B

Dependent variable: $=1$ if school interview occurred and pupil outcomes available

\begin{tabular}{|c|c|c|c|c|c|c|c|c|}
\hline \multirow[t]{2}{*}{$\log$ (pupils) } & 0.072 & $0.214^{* * *}$ & & $-0.212 * *$ & & 0.054 & $0.274 * *$ & 0.011 \\
\hline & $(0.054)$ & $(0.069)$ & & $(0.086)$ & & $(0.168)$ & $(0.124)$ & $(0.057)$ \\
\hline \multirow[t]{2}{*}{$\begin{array}{l}\text { Regular Government } \\
\text { Schools }\end{array}$} & $0.322 * * *$ & & & 0.001 & & 0.104 & -0.082 & $0.713 * * *$ \\
\hline & $(0.106)$ & & & $(0.108)$ & & $(0.216)$ & $(0.111)$ & $(0.147)$ \\
\hline \multirow[t]{2}{*}{$\begin{array}{l}\text { Log(population density } \\
\text { in the region) }\end{array}$} & -0.043 & $0.251 * * *$ & & $-0.093 *$ & & -0.074 & $0.082 *$ & 0.045 \\
\hline & $(0.038)$ & $(0.076)$ & & $(0.054)$ & & $(0.072)$ & $(0.049)$ & $(0.050)$ \\
\hline Observations & 847 & 754 & 379 & 678 & 348 & 230 & 1339 & 1298 \\
\hline
\end{tabular}

Notes: Probit with marginal effects. Robust standard errors in parentheses. $\mathrm{BR}=\mathrm{Brazil}$, $\mathrm{CA}=\mathrm{Canada}$, $\mathrm{DE}=$ Germany, IN=India, IT=Italy, $\mathrm{SE}=$ Sweden, UK=United Kingdom, US=United States. Regular Government Schools refers to the percentage of regular government schools which are funded \& managed exclusively by government authorities (this excludes private and autonomous government schools). This information is not available for Canadian schools. Population density is at the state-level in Brazil, India, and the US, province-level in Canada, and NUTS 2 regions in Germany, Italy, Sweden and the UK. 
Canada, private ersatzschulen in Germany, friskolor in Sweden, academies, foundation, and voluntary-aided schools in the UK, and charter and magnet schools in the US. Population density is at the NUTS3 level. The competition variable is collected during the survey itself by asking the principal "How many other schools offering education to 15 year-olds are within a 30-minute drive from your school?" STEM background refers to principals with a background in Science, Technology, Engineering, Maths, and Business. The autonomy questions were asked and measured during the survey. For personnel autonomy, we ask "To hire a full-time teacher what agreement would you need?, for budgetary autonomy, we ask "What is the largest capital investment you can make without prior authorization from outside?" and for academic content autonomy, we ask "To add a new class - for example, introducing a new language such as Mandarin - what agreement would you need?". To measure the degree of autonomy we use a $1-5$ scale where 1 refers to no authority to make any decision and 5 refers to complete authority to make any decision. Principal accountability variable measures the degree to which the principal is responsible for delivering the school targets and the principal strategy variable measures the degree to which the principal communicates a wellestablished strategy for the school for the next 5 years. 